\title{
The Experiences of Merging Health Insurance Funds in Turkey, Thailand, South Korea and Indonesia: What lessons can be learned?
}

\section{Mohammad Bazyar}

Ilam University of Medical Sciences

Arash Rashidian

Tehran University of Medical Sciences

Vahid Yazdi-Feyzabadi

Kerman University of Medical Sciences

Anahita Behzadi ( $\square$ anahitabehzadi1984@gmail.com )

Kerman University of Medical Sciences

Research article

Keywords: fragmentation, risk pooling, merging, single insurance

Posted Date: April 1st, 2020

DOl: https://doi.org/10.21203/rs.3.rs-15701/v2

License: (c) (i) This work is licensed under a Creative Commons Attribution 4.0 International License. Read Full License 


\section{Abstract}

Background : Fragmentation in health insurance system can obstruct reaching universal health coverage' objectives and may lead to inequity in financial and organizational access to health care services. One possible option to overcome this challenge is merging the existing insurance funds together. This article aims to review the experience of Turkey, Thailand, South Korea and Indonesia regarding merging which can be very useful for other countries which are looking for ways of enhancing their health systems. Methods: The present study is a cross-country comparative analysis. The first criterion to choose these countries was with experience of the policy of merging. The second criterion was diversity in health insurance systems. To find the most relevant documents about the subject, different sources of information were searched including books, scientific papers, reports, policy documents and documents published by international organizations such as WHO and World Bank. We followed snowball sampling method to reach out for further documents by checking the reference list of the most relevant documents. We also contacted the authors with the most relevant articles in the selected countries to introduce and provide us with more articles or publications about the subject. Results: The experience of Turkey, Thailand, South Korea and Indonesia show that different reasons may force policy makers to move towards merging and reducing the number of health insurance funds; different stakeholders may support or oppose merging based on the interests they may have in the current fragmented health insurance system; various positive and negative consequences may occur in the health system as the result of merging. The experience of these countries also emphasize that in order to accelerate and facilitate implementation process of merger and face less operational challenges, there should be some prerequisites such as experiencing reliable economic growth to enhance benefit package and support the single national insurance scheme financially after merging. Conclusions: Merging is not the panacea to all problems of health system and other contributing health reforms should be implemented simultaneously or sequentially in other aspects of health system if merging is going to pave the way reaching universal health coverage.

\section{Background}

In many countries with health insurance system, various insurance schemes coexist which lead to the fragmentation of health insurance schemes and reduction of risk pooling ${ }^{1,2}$. This fragmentation creates concerns regarding equity in access to health services among different groups of population as well as financial instability for small funds ${ }^{3}$. Fragmentation can also postpone reaching universal health coverage' objectives such as reduction the financial burden as it reduces the potential degree of risk redistribution from a given amount of prepaid funds ${ }^{4}$. Fragmentation as a concern in health insurance system ${ }^{5,6}$ has been addressed in WHO' world health reports 2000, 2008 and 2010 $7-9$. Also, the World Bank has warned the Eastern Asian countries against the high administrative costs of multiple health insurance funds, duplication of benefit packages, and loss of negotiation power with health services providers ${ }^{3}$. 
Because of that, one of the main concerns in health financing reforms which most countries are looking for is a guide for proper implementation of single and multi-payer health insurance systems. In the singlepayer system, one organization, which is usually the government, carries out the tasks of collecting and pooling revenues, and purchasing health services for the entire population of the country while in multipayer systems these tasks are done by several organizations. In the single-payer system, there is a single fund and all financial risks are pooled within it while in multi-payer systems there are multiple funds which lead to fragmentation in risk pools. The single-payer system has the exclusive power for purchasing services, but in multi-payer systems, people belong to different insurance organizations ${ }^{10,11}$.

Studies show that achieving universal health coverage for the entire population requires various forms of cross-subsidies including the subsidy shift from the rich to the poor, from healthy to unhealthy people, and from low-risk persons like the young to the high-risk ones such as adults and the elderly. Many middle-income countries such as Brazil, Indonesia, Philippines, Turkey, and South Korea are trying to reduce the disparity in accessing health service through providing universal health coverage, enhancing health insurance funds based on pre-payment procedures and implementing health system enhancement programs $^{12}$.

In countries in which there are official and compulsory insurance funds as well as funds with a significant number of beneficiaries, integrating and merging the existing funds is one possible option to boost health insurance system and move towards achieving universal health coverage ${ }^{13}$. This policy is more applicable in countries where there is no competition among health insurance schemes or moving towards competition is expensive as the required conditions are not available ${ }^{14}$. Some countries have applied this approach for extending the size of insurance funds, improving equity and justice, and improving risk pooling ${ }^{13,15}$. In other countries, health reforms have led to a decrease in the number of funds. For instance, in Estonia, in 2001 and in Poland, in 2003, 17 regional funds were merged to form a single national fund ${ }^{16}$.

Indonesia and Peru are also moving toward integration of risk pools as the last step in universal health coverage. In November 2011, Indonesia passed a law which obligated the five governmental health funds which covered separate population groups, to merge under a comprehensive program aimed to benefit from cross subsidy, reducing administrative costs and providing more equitable benefit benefits ${ }^{17}$. Indonesia officially implemented the National Health Insurance program on January 1, 2014. This program consists of the merger of programs which were previously covered by government and other social security insurance programs, but now will become a single-payer and cover all citizens ${ }^{15,18}$. In Peru, the Universal Health Insurance Law of 2010, created an obligatory framework for achieving universal health coverage through coordinated process of merging two main social insurance funds ${ }^{15}$. Also, Turkey undertook extensive reforms in order to merge different insurance schemes and achieved integration and cross-subsidization. Brazil merged different programs under SUS according to constitution of 1988 which was financed through general taxation. Thailand merged two main programs under the universal health coverage in 2001 and with the highest number of insured members being in this fund, cross-subsidization 
and financial security were guaranteed. However, there are still three funds in Thailand and the per capita cost across these funds is very unstable due to the lack of redistribution of resources. Ghana has taken some measures towards fund integration. Ghana has a single risk pool under the national health insurance, which transfers resources from the rich to the poor through progressive general taxation and the redistributive function of the national health insurance program. In Vietnam, efforts to integrate funds are still ongoing. However, the real pooling of resources and distribution of costs are not fully implemented ${ }^{15}$.

Although success of health reforms is dependent on how well they are developed and implemented technically, they are facilitated or inhibited by a wide range of social, economic, political and cultural factors which is different from one country to another. This clarifies that moving toward to single-payer in health insurance is context-sensitive and cross-country comparison among different countries provide proper evidence for policy makers across the world particularly developing countries which are a focus of this study.

The experience of countries which have moved toward consolidation of health insurance funds as the main strategy for achieving universal health coverage, especially in recent years, could be very useful for developing countries and countries which are looking for ways of enhancing and extending their health systems. This is due to the fact that identifying operational challenges and obstacles in the process of merging of funds and its advantages and disadvantages will provide proper evidence for policy making in this sector as well as useful lessons for moving toward the fund merging policy. Therefore the present study was conducted aiming at a comparative analysis of the experiences of four Asian countries namely, Turkey, Thailand, South Korea and Indonesia in establishing national unified insurance or reducing the number of funds.

\section{Method}

The present study is a cross-country comparative analysis which was conducted aiming to investigate the experiences of four Asian countries, namely Turkey, Thailand, South Korea and Indonesia, regarding the policy of merging and reducing the number of insurance funds. The first criterion to choose these countries was that all of them have moved toward the policy of merging health insurance funds and moved from a multi-payer system toward a single-payer system or toward the reduction of the number of funds. Therefore, countries already with a single payer for covering the health care services for the whole population were naturally excluded from the study since in these countries fund merging is meaningless. The second criterion was diversity in health insurance systems. The selected countries provide a diverse range of health insurance systems with different number of funds and with different degrees of success in implementing merger. For instance, the insurance system of Turkey with several main funds and South Korea with hundreds of funds before the merger of funds currently have one health insurance organization which is a unified insurance covering the entire population. However, in Turkey, Armed Forces medical insurance has remained independent due to military considerations. Thailand has implemented merging partly and Indonesia currently having multiple funds across county is moving 
toward a uniform health insurance. Of course, there are countries with competitive health insurance funds, despite their diverse insurance structures, are not moving toward merging, and therefore, are not suitable for the study.

The main aspects of merger that we focus on in each country included the reasons behind moving towards reducing fragmentation in health insurance schemes and merging them together; structure of health insurance system before and after merger; the process of merger; the positive and negative consequences of merger; the stakeholders, opponents and proponents of the merger; the resistance against and facilitators of the merger; the simultaneous and contributing health reforms alongside merger; and finally the general conditions of the country and the health system which facilitate or hinder the process of merger.

To find the most relevant documents about the subject, different sources of information were searched including books, scientific papers, reports, policy documents and documents published by international organizations such as WHO and World Bank, using the following key words:

merger/combination/consolidation/amalgamation of health insurance funds, fragmentation in health financing, multiple health insurance, single health insurance, multiple and single payer, risk pooling, health insurance, and health financing. We use different combination of key words in searching for scientific articles in PubMed, Google Scholar, and Science Direct. Furthermore, we use the same key words to search through the websites of national and international organizations. We focus exclusively on English language documents. Although few available Farsi documents were searched and reviewed which were mainly translation of English documents. We followed snowball sampling method to reach out for further documents by checking the reference list of the most relevant documents. As to the best of authors' knowledge, the studies in this area are not rich we also sent emails to the authors with the most relevant articles in the selected countries to introduce and provide us with other missing relevant articles or publications about the subject. With this policy more relevant documents were extracted.

\section{Results}

The first thing we should bear in mind is that acing fragmented health insurance system does not mean it should be eliminated. The degree of differences among health insurance schemes in terms of following 5 criteria can be used to assess the quality and performance of the health insurance system with multiple risk pools. The bigger differences, the more we should be worried about the fragmentation. These criteria include the percent of the whole population under coverage of each health insurance scheme; the extent of differences in the premiums, benefit package, quality of health care received by members of different risk pools, and more importantly variations in user charges and amount out-of-pocket paid by different beneficiaries belong to different insurance schemes for the same health services they use ${ }^{1}$. So no matter how many health insurance funds exist in a given country, for instance less than 10 or more than hundred, the status quo in terms of above indicators is more important. As we see in the following sections, inequality in health financing and access to different benefit packages among different groups of people were common motives in the selected countries to merge and create a single national scheme 
for all. These differences among risk pools in countries even with only several insurance schemes such as Turkey and Thailand and Indonesia made policy makers to move towards merging as a solution to end up inequity in health care services. In contrast in some OECD countries with multiple risk pools such as the Slovak Republic, the Czech Republic, Switzerland and France the performance of the health insurance system in terms of equity in above indicators is satisfactory as health insurance schemes are mandated to provide the same benefit package by getting the same contribution rates, so no matter which scheme the beneficiaries belong to, they access to the same health services ${ }^{19}$. It is not astonishing that bigger gaps in the above areas make moving towards merging more difficult as the experience of countries like Iran shows that those schemes with better financial resources and benefit packages concern about sharing these benefits with other underprivileged groups of population ${ }^{20,21}$, so it can be said when the situation is not satisfactory, although it makes addressing the fragmentation more justifiable, it would be more challenging. In the following sections we try to review the experience of the selected countries individually regarding merger referring to the above criteria as much as feasible to see how these countries managed to solve the problems, why they failed and what made the process of merging easier or more difficult.

Table 1 shows the general health financing indicators in the selected countries.

\section{Table 1: General characteristics of health financing indicators in selected countries}




\begin{tabular}{|c|c|c|c|c|}
\hline & Turkey & $\begin{array}{c}\text { South Korea } \\
\text { (2011) }\end{array}$ & $\begin{array}{l}\text { Thailand } \\
\text { (2012) }\end{array}$ & $\begin{array}{l}\text { Indonesia } \\
\text { (2014) }\end{array}$ \\
\hline Classification by income level & $\begin{array}{l}\text { Upper-middle- } \\
\text { income }\end{array}$ & High-income & $\begin{array}{l}\text { Upper-middle- } \\
\text { income }\end{array}$ & $\begin{array}{l}\text {-Lower-middle- } \\
\text { income }\end{array}$ \\
\hline $\begin{array}{c}\text { Gross national income per capita (PPP } \\
\text { international \$, 2013) }\end{array}$ & 18,760 & 33,440 & 13,510 & 9,260 \\
\hline $\begin{array}{l}\text { Total expenditure on health per capita (Intl \$, } \\
\qquad 2014 \text { ) }\end{array}$ & 1,036 & 2,531 & 600 & 299 \\
\hline Total health expenditure as $\%$ of GDP & 6.1 & 7.4 & 4.5 & 2.8 \\
\hline $\begin{array}{l}\text { Public expenditure on health as \% of total } \\
\text { expenditure in health }\end{array}$ & 73 & 55.3 & 76 & 37.8 \\
\hline $\begin{array}{l}\text { Private expenditure on health as \% of total } \\
\text { expenditure in health }\end{array}$ & $27-37$ & 44.7 & 24 & 62.2 \\
\hline $\begin{array}{c}\text { Government health spending as } \% \text { of total } \\
\text { government spending }\end{array}$ & $9.8-13.9$ & 15.2 & 11 & 5.7 \\
\hline $\begin{array}{c}\text { OOP payments as } \% \text { of total expenditure on } \\
\text { health }\end{array}$ & 17.4 & 35.2 & 11.6 & 46.9 \\
\hline
\end{tabular}

\section{South Korea}

\section{Health insurance system in South Korea before and after merging}

Before the merger of all insurance schemes in Korea in 2000, there were three social health insurances for: (1) government employees and teachers and their relatives (one fund), (2) industrial workers and their relatives with nearly 140 insurance schemes and (3) the self-employed and workers in firms with less than 5 workers, with nearly 230 insurance schemes (92 funds in rural and 135 fund in urban areas). Also, there was another scheme called Medicaid for the poor which covered 3-5\% of the remaining population. Health insurance for employees was based on where they worked and, for the self-employed, on where they lived. For the health scheme of employees, large companies had their own insurance while small and medium-sized companies were a part of insurance schemes existing in their geographical area ${ }^{22}$. Table 2 shows more details of the insurance system.

Table 2: Social health insurance structure in South Korea before and after the merger 


\begin{tabular}{|c|c|c|c|c|c|c|}
\hline & & Scheme & $\begin{array}{l}\text { Population } \\
\text { eligibility }\end{array}$ & Benefit package & Financing & Affiliation \\
\hline \multirow[t]{4}{*}{$\begin{array}{l}\text { South } \\
\text { Korea }\end{array}$} & \multirow[t]{4}{*}{ Before } & $\begin{array}{l}\text { (A single) } \\
\text { social health } \\
\text { insurance } \\
\text { scheme, } \\
1979\end{array}$ & $\begin{array}{l}\text { government } \\
\text { employees } \\
\text { and teachers } \\
\text { and their } \\
\text { dependents } \\
\text { (based on } \\
\text { employment) }\end{array}$ & $\begin{array}{l}\text { The benefit package of } \\
\text { health insurance mainly } \\
\text { includes curative services, } \\
\text { but includes biannual } \\
\text { health checkups and } \\
\text { vaccination is provided } \\
\text { free of charge in public } \\
\text { health centres } \\
\text { Benefit package was the } \\
\text { same for all in South } \\
\text { Korea even before the } \\
\text { merger of insurance } \\
\text { societies in } 2000\end{array}$ & $\begin{array}{l}\text { For industrial workers and } \\
\text { government and school } \\
\text { employees, contribution is } \\
\text { proportional to wage } \\
\text { income and shared equally } \\
\text { between the employee and } \\
\text { employer. Before the } \\
\text { merger of insurance } \\
\text { societies in } 2000 \text {, the } \\
\text { average contribution rate } \\
\text { was } 5.6 \% \text { (of wage income) } \\
\text { for government and school } \\
\text { employees. }\end{array}$ & $\begin{array}{l}\text { the } \\
\text { Ministry } \\
\text { of Health } \\
\text { and } \\
\text { Welfare }\end{array}$ \\
\hline & & $\begin{array}{l}140 \text { social } \\
\text { health } \\
\text { insurance } \\
\text { schemes, } \\
1977\end{array}$ & $\begin{array}{l}\text { for } \\
\text { industrial } \\
\text { workers and } \\
\text { their } \\
\text { dependents }\end{array}$ & " & $\begin{array}{l}\text { For industrial workers and } \\
\text { government and school } \\
\text { employees, contribution is } \\
\text { proportional to wage } \\
\text { income and shared equally } \\
\text { between the employee and } \\
\text { employer. } 3.75 \% \text { for } \\
\text { industrial workers, with a } \\
\text { range of } 3.0-4.2 \% \\
\text { depending on the } \\
\text { insurance society }\end{array}$ & $\begin{array}{l}\text { the } \\
\text { Ministry } \\
\text { of Health } \\
\text { and } \\
\text { Welfare }\end{array}$ \\
\hline & & $\begin{array}{l}\text { about } 230 \\
\text { health } \\
\text { insurance } \\
\text { societies (92 } \\
\text { in rural and } \\
135 \text { in } \\
\text { urban } \\
\text { areas), } 1981\end{array}$ & $\begin{array}{l}\text { for the self- } \\
\text { employed } \\
\text { and workers } \\
\text { in firms } \\
\quad \text { with less } \\
\text { than five } \\
\text { employees, } \\
\text { based on } \\
\text { residential } \\
\text { area }\end{array}$ & $"$ & & $\begin{array}{l}\text { the } \\
\text { Ministry } \\
\text { of Health } \\
\text { and } \\
\text { Welfare }\end{array}$ \\
\hline & & $\begin{array}{l}\text { Medicaid, } \\
1977\end{array}$ & $\begin{array}{l}\text { for the poor } \\
\text { (3-5\% of the } \\
\text { population) }\end{array}$ & " & & $\begin{array}{l}\text { the } \\
\text { Ministry } \\
\text { of Health } \\
\text { and } \\
\text { Welfare }\end{array}$ \\
\hline & After & $\begin{array}{l}\text { the National } \\
\text { Health } \\
\text { Insurance } \\
\text { Corporation } \\
\text { (NHIC), } \\
2000\end{array}$ & $\begin{array}{l}\text { All } \\
\text { population }\end{array}$ & " & $\begin{array}{l}\text { As of } 2006, \text { the } \\
\text { contribution rate was } \\
4.48 \% \text { (NHIC 2007). }\end{array}$ & \\
\hline
\end{tabular}




\section{Policy objectives: reasons behind moving toward merging of insurance funds in South Korea}

In South Korea, health financing was not reformed to control or reduce the costs; but the inequity in financing and differences in financial capacities of insurance funds and other problems discussed in following were among the main concerns for undertaking reforms (10). Before merging the social health insurance reimbursed the providers based on a fixed fee schedule. This forced the providers to resort to cost shifting and imposed higher fees on the uninsured persons which in turn led to exacerbating the inequity in access to health services ${ }^{22}$. Inequity in health financing across different income and job groups, differences in financial capacity across insurance funds, and chronic financial instability of some rural insurance funds stimulated the foundational change in the national insurance structure ${ }^{14}$. Before the merger, many funds were small and unable to integrate their resources effectively. Also, due to the lack of competition, the funds did not have any tendency to merge and improve risk pooling ${ }^{14,23}$. Moreover, for the self-insured members in poor areas, the portion of income assigned to insurance, was greater than it was in rich areas. There was horizontal inequality since in some areas people with a similar income would pay different contributions for the same benefits based on their insurance type ${ }^{14}$. The government introduced health insurance for the self-employed due to the inequity in payments for health care services between the insured and the uninsured. In 1998, before the merger, health insurance schemes for the self-employed gained $10.9 \%$ of their total revenue from risk equalization fund, however financial problems of insurance funds in some rural areas were still an issue. Therefore, the government decided to merge all of the schemes in $2000^{22,24}$.

\section{Process of merging:}

In South Korea the process of merging began with the health insurance funds for self-employed workers, teachers and government employees in October 1998 and by merging these schemes together the National Health Insurance Corporation (NHIC) was created. In July 2000, the funds for industrial workers were merged with the NHIC, and the national health insurance of Korea became a single payer insurance system. The NHIC had separate funds for government and school employees, industrial workers and the self-employed. The insurance funds for industrial workers and government and school employees were merged together in 2001 and this new fund was merged with the fund of the self-employed in 2003. Therefore, the single payer system was established in $2003^{14}$. In Korea, ass claim review and payment to health care providers were centralized even before the merger and all health insurance schemes followed the same statutory benefit packages, the process of merging didn't face challenges in these areas ${ }^{22}$.

\section{Facilitators of merging:}

\section{Leadership and Political commitment:}


In South Korea, several factors were influential in facilitating the process of merging. The main political contributing factors were the president, Chun Doowhan, and the presidential candidate of the ruling party, Roh Taewoo, who were looking for political support and legitimacy, suggested the universal health insurance coverage $\mathrm{e}^{23}$. The political regime and motivation for political legitimacy played key roles in the introduction and development of the social health insurance. Politicians who had constituents in rural areas advocated the merger of insurance schemes. Farmers, the poor in urban areas, academics and civil groups were also among the early advocates of uniform financing systems ${ }^{22}$. The residence-based municipal health insurance societies that were suffering from serious financial problems due to covering lower-income and older people and trade unions in the mid-1990s that focused on the redistribution and solidarity across different income groups rather than occupational differences were among the supporters of merging health insurance schemes ${ }^{25}$.

\section{Neutrality of potential opposing groups such as physicians:}

In South Korea, the neutrality of these groups helped the structural changes in health insurance system ${ }^{14}$. Physicians were neutral as they were not directly affected by the outcomes of the integration reform. Instead, they were concerned about the fee schedule and the reforms on the payment system ${ }^{25}$.

\section{Economic growth and stability and financial feasibility:}

In South Korea, the expansion of the health insurance to the self-employed or the workers in the informal sector was a significant challenge for the Universal Coverage scheme. Economic and political factors facilitated the expansion of the insurance to the self-employed, which was the last group that joined the National Health Insurance. The economic growth of the 1980s improved the financial power of the selfemployed to pay for the insurance. At that time, the economic growth increased by 12 percent. Also, the

government had the financial power to subsidize the self-employed ${ }^{23}$. A strong political regime and significant economic growth were effective on the compulsory registration for insurance and cooperation of employers to pay half of the contributions of the employees; and there were few problems related to false reports of wages or evading registration ${ }^{22,26}$. Other facilitators were mandatory participation and well-established information technology infrastructures. The government made it obligatory for insurers and providers to participate with $\mathrm{NHI}$ and all people were obliged to enroll in the national scheme and information technology made the following activities possible which are necessary for merging and extending the health insurance including eligible criteria management, benefit management, claims review etc ${ }^{26}$.

\section{The resistances and limitations ahead of the merger:}

\section{Opposition aroused by population groups enjoying better benefit package:}

In order to merge the funds and create a national health insurance to provide equal benefit packages for all, it may be necessary for the government to make greater investments and provide more financial support to develop infrastructures in rural and remote areas for the underprivileged groups. In Korea, 
unlike the industrial workers, the extension of insurance to the self-employed faced tough resistance. Farmers wanted a rise in government subsidies and development of health centers in rural areas to improve their access. The government was forced to comply. At first, the government subsidy to the selfemployed was about half of the total revenue of the self-employed insurance fund ${ }^{22}$. In Korea, despite high migration rates from rural areas to urban areas, they did not face any serious challenge in this regard as benefit packages of different schemes were the same even before the merger of funds ${ }^{22}$.

\section{Concerns of workers and employers about increase in contribution rates:}

In Korea, the employers, large corporations which paid half of the contribution of the employees and those with high incomes and low risks were among the potential opponents, since they were concerned that due to the problem of income assessment in the self-employed, the unified insurance system would place more pressure on industrial employers and workers to pay their contribution ${ }^{22}$. The company-based health societies which provided exclusive benefits for their employees were against integration as they believed that integration would lead to eliminating the company-based health societies and in turn the company-based welfare programmes ${ }^{25,27}$.

\section{Concerns about identifying and setting rational contribution rates for informal workers:}

Also, in countries that a large part of the population is active in the informal sector, there are problems related to identifying and collecting contributions of the self-employed, part-time workers, and seasonal workers $^{28}$. In Korea, the problem of identifying the income and contribution of the self-employed was the main problem to integrate financial contributions of employees and the self-employed ${ }^{29}$.

\section{Opposition aroused by trade union concerning about downsizing:}

In Korea, the structural change and reduction of personnel was one of the intended goals of National Health Insurance system which was faced with the strong opposition by the trade union that was the representative of its employees. This opposition was a serious barrier to achieve expected reduction in the number of personnel and overall administrative costs ${ }^{14}$.

\section{The merging policy positive consequences:}

It is worth to specify that what kind of problems can be solved by consolidation of health insurance schemes in the health system and health financing area. Also, the clear explanation of potential achievements can be effective on supporting the implementation of the program and reducing the resistances by opposing actors. In South Korea, the following benefits can be mentioned as the consequences of consolidation:

\section{Improving health financial equity}

Combination of health insurance schemes, changing financial flows, and increase of the power of health insurance system as a result of combination, can significantly and positively improve the equity in health 
financing. Although health equity improvements can't be attributed only to consolidation or reduction in the numbers of health insurance funds, they have been the most important ones. For instance, in South Korea, the merger of health funds of the self-employed created the same contribution rates for all the selfemployed across the country. The National Health Insurance considered some discounts for underprivileged groups based on their income and geographical location. $62 \%$ of the households were paying a lower contribution compared to the times before the merger while the residents of one the richest counties in Seoul paid greater contribution (36.3\% increase in average rate) than before the merger. Therefore, the merger had improved the equity in financing among the self-employed society ${ }^{14}$. On the other hand, the uniform system had improved the contribution equity among the industrial workers. The equalization of the contribution rates after the merger of the industrial workers funds showed that $56 \%$ of the insured pay a lower contribution. The contribution of the employees with more than 1300 US dollars' income increased. This meant that the more they earned the higher contribution they paid. The amount of changes in contribution differed based on the number of employees. The contribution of the employees of firms with less than 10 employees was reduced by $17 \%$ while the contribution of the employees of firms with more than one thousand employees increased by $19.4 \%{ }^{14}$.

\section{Reducing the administrative costs}

In Korea, many funds did not have economies of scale due to their small size, and it seemed that the merger would reduce the administrative costs. Before the merger, the administrative costs were $4.8 \%$ for the Health Insurance Scheme of the government and school employees (the single insurance), and 9.5\% for the insurance scheme of the self-employed. In 2004, the administrative costs of the National Health Insurance were reduced to $4 \%$ of the total costs ${ }^{22}$. In Korea, after the merger of the regional funds of the self-employed with the fund of government employees and school teachers in 1998, 227 insurance funds

of the self-employed and 19 funds of the government employees were reduced to 162 regional funds, and the number of personnel was reduced from 10849 to 9073 in December $1999{ }^{14}$.

\section{The probable risk and negative consequences of merging:}

\section{Risk of moral hazard and catastrophe of shared resources}

According to the experience of South Korea, the single payer system might face moral hazards. Before the merger, each fund is responsible for its own financial outcomes, and the insured are interested in the financial saving and keeping their own fund financially sustainable. However, after the merger, they may be less concerned about controlling health expenditures, and health service utilization may increase. As the financial resources are shared with the whole population, collection of the contributions from the selfemployed may not be done as actively as before ${ }^{14}$.

\section{Risk of facing more politics and less flexibility in making health insurance decisions at national level}

After the merger and under a single insurance system, major decisions on the health insurance, such as adapting premiums and benefit packages, will become national issues rather than being a local concern. 
For instance, the process of adjusting contributions to cope with increasing health costs will mostly be political and less flexible ${ }^{14}$. However, the single insurance system can provide this opportunity to highlight some neglected health insurance policy decisions previously in the fragmented health insurance system at a national level ${ }^{14}$.

\section{Need for more financial support by the government}

One issue that must be considered while merging insurance funds is that the long-term financing of the single fund must be guaranteed. In South Korea, the National Health Insurance program has experienced financial instabilities. Those opposing the merger claim that moral hazards and inflexibility in increasing the contributions after the merger have caused financial crises. In most countries, government engage financially only in some public schemes or for some groups of population, while after merging, the single national scheme needs more support by the government in financing since the financial instability of the single insurance system emphasizes the need for the intervention of government ${ }^{14}$.

\section{Other contributing health reforms alongside merging:}

\section{Need for moving towards close ended payment methods}

It is worth mentioning that South Korea policy makers have tried to applied close-ended methods of payment in order to lead to an increase in efficiency, a decrease in costs, and reasonable use of services. In South Korea, since the beginning of the National Health System, fee-for-service payment has been used to reimburse the providers, which has led to an increase in the volume of health services utilization. In order to change the fee-for-service system into a prospective DRG system, the new system was implemented voluntarily as a pilot study in some health care institutes. The results were positive, and it had positive effects on the behavior of the providers. However, due to the oppositions of providers, the new system was not expanded to all providers. Currently, changing the payment system into DRG or capitation is one of the main challenges of the health insurance system ${ }^{22}$. To increase the financial stability of the national schemes, emergency and accident health services are reimbursed by a separate central fund ${ }^{30}$.

\section{Future Challenges:}

Despite admirable progress in extending population coverage by creating $\mathrm{NHI}$, it has not been so successful in some health financial indicators according to the three aspects of universal health coverage. OOP expenditures have been high compared to the OECD countries and it was $36.8 \%$ in 2015 while the average was $19.5 \%$ in $\mathrm{OECD}^{26}$. The performance of $\mathrm{NHI}$ has not been satisfactory in terms of extending health services coverage and financial protection which has imposed high pressure on the underprivileged groups. This caused the Korean Government to introduce a NHI reform in August 2017 known as "Moon Jae-in Care" to improve NHI by including all uninsured services into the insurance benefit package ${ }^{26}$. 


\section{Turkey}

\section{Health insurance system before and after the merging:}

There were 5 funds in Turkey before the merger as follows: 1- The Social Insurance Organization (SIO) which provided health services and pension for employees of the private sector, blue collar workers of the public sector and agricultural workers as well as their dependents, and it covered $47.91 \%$ of the entire population in 2007. 2-Bag-Kur or the Social Insurance Agency for Merchants, Artisans and the Selfemployed which covered the self-employed, comprising include $22.5 \%$ of the population. This scheme does not directly provide medical services, but purchases the required services through contracting with public and some private health sector. 3- The Government Employees Retirement Fund (GERF) which was a combination of health insurance and pension fund covered $15 \%$ of the population in 2007. This fund covered in-patient and outpatient services. Similar to the Bag-Kur, this fund did not have medical centers of its own and purchased services from the public or private sector. 4- The Government Employees Insurance Fund 5- The Green Card Program: In 1992, the government introduced the Green Card Program for helping the poor who could not pay for in-patient services ${ }^{31-34}$. The number of people having the Green Card was more than 14 million in 2007. More information about the Turkey health insurance system has been shown in Table 3.

Table 3: Social health insurance structure in Turkey before and after the merger 


\begin{tabular}{|c|c|c|c|c|c|c|}
\hline & & Scheme & $\begin{array}{l}\text { Population } \\
\text { eligibility }\end{array}$ & Benefit package & Financing & Affiliation \\
\hline \multirow[t]{4}{*}{ Turkey } & \multirow[t]{4}{*}{ Before } & $\begin{array}{l}\text { SSK (the } \\
\text { Social } \\
\text { Insurance } \\
\text { Organisation), } \\
1945\end{array}$ & $\begin{array}{l}\text { blue collar } \\
\text { workers } \\
(49.49 \%)\end{array}$ & $\begin{array}{l}\text { Pre-paid short-term medical } \\
\text { and maternal benefits, } \\
\text { employment related } \\
\text { accident and occupational } \\
\text { disease benefits; long-term } \\
\text { benefits for old age, } \\
\text { disability and survivor } \\
\text { pensions; did not provide or } \\
\text { pay for preventive services }\end{array}$ & $\begin{array}{l}\text { Employees ( } 5 \% \text { of } \\
\text { salary), employers } \\
(6 \%), \text { state } \\
\text { subsidized ( } 8.5 \% \\
\text { employer share } \\
5 \% \text { employee } \\
\text { share) }\end{array}$ & $\begin{array}{l}\text { Attached to } \\
\text { the Ministry } \\
\text { of Labour } \\
\text { and Social } \\
\text { Security } \\
\text { until May } \\
2006 \text {, } \\
\text { transferred } \\
\text { to the } \\
\text { Social } \\
\text { Security } \\
\text { Institution }\end{array}$ \\
\hline & & $\begin{array}{l}\text { Bağ-Kur, } \\
1971\end{array}$ & $\begin{array}{l}\text { self- } \\
\text { employed } \\
\text { people, } \\
\text { artisans, } \\
\text { and } \\
\text { organised } \\
\text { groups } \\
(23.43 \%)\end{array}$ & $\begin{array}{l}\text { All outpatient and inpatient } \\
\text { diagnosis and treatment. } \\
\text { The insured were required } \\
\text { to pay } \\
\text { health insurance premiums } \\
\text { for at least } 8 \text { months and } \\
\text { have no record of default of } \\
\text { health insurance and long } \\
\text { term insurance premiums }\end{array}$ & $\begin{array}{l}20 \% \text { premiums } \\
\text { collected from } \\
\text { beneficiaries. The } \\
\text { scheme worked } \\
\text { on a } \\
\text { reimbursement } \\
\text { system }\end{array}$ & $\begin{array}{l}\text { Attached to } \\
\text { the Ministry } \\
\text { of Labour } \\
\text { and Social } \\
\text { Security } \\
\text { until May } \\
2006 \text {, } \\
\text { transferred } \\
\text { to the } \\
\text { Social } \\
\text { Security } \\
\text { Institution }\end{array}$ \\
\hline & & $\begin{array}{l}\text { Emekli Sandigi } \\
\text { (the } \\
\text { Government } \\
\text { Employees } \\
\text { Retirement } \\
\text { Fund), } 1949\end{array}$ & $\begin{array}{l}\text { Retired civil } \\
\text { servants } \\
\text { and their } \\
\text { dependents } \\
(13 \%)\end{array}$ & $\begin{array}{l}\text { Diagnosis and } \\
\text { treatment }\end{array}$ & $\begin{array}{l}20 \% \text { of the } \\
\text { deduction of the } \\
\text { Government } \\
\text { Employees } \\
\text { Retirement Fund } \\
\text { (State share as } \\
\text { employer), 16\% of } \\
\text { the deduction of } \\
\text { the Government } \\
\text { Employees } \\
\text { Retirement Fund } \\
\text { (participant } \\
\text { share) for both } \\
\text { health and } \\
\text { pension; funded } \\
\text { through the } \\
\text { contributions of } \\
\text { the active civil } \\
\text { servants and their } \\
\text { employers } \\
\text { (general budget } \\
\text { revenues) }\end{array}$ & $\begin{array}{l}\text { Attached to } \\
\text { the Ministry } \\
\text { of Labour } \\
\text { and Social } \\
\text { Security } \\
\text { until May } \\
2006 \text {, } \\
\text { transferred } \\
\text { to the } \\
\text { Social } \\
\text { Security } \\
\text { Institution }\end{array}$ \\
\hline & & $\begin{array}{l}\text { the Active } \\
\text { Civil Servants } \\
\text { Insurance } \\
\text { Fund, } 1965\end{array}$ & $\begin{array}{l}\text { civil } \\
\text { servants in } \\
\text { work and } \\
\text { their } \\
\text { dependents }\end{array}$ & $\begin{array}{l}\text { Diagnosis and } \\
\text { treatment }\end{array}$ & $\begin{array}{l}\text { Benefits were } \\
\text { financed by } \\
\text { general tax } \\
\text { revenues; no } \\
\text { premiums were }\end{array}$ & $\begin{array}{l}\text { Attached to } \\
\text { the Ministry } \\
\text { of Finance } \\
\text { through } \\
\text { their }\end{array}$ \\
\hline
\end{tabular}

Page 15/44 


\begin{tabular}{|c|c|c|c|c|c|}
\hline & & & & $\begin{array}{l}\text { assessed } \\
\text { for active civil } \\
\text { servants while } \\
\text { they were } \\
\text { covered directly } \\
\text { through their } \\
\text { employers }\end{array}$ & $\begin{array}{l}\text { institutions } \\
\text { until } 2010 \text {, } \\
\text { transferred } \\
\text { to the } \\
\text { Social } \\
\text { Security } \\
\text { Institution } \\
\text { in } \\
\text { January } \\
2010\end{array}$ \\
\hline & $\begin{array}{l}\text { the Green } \\
\text { Card, } 1992\end{array}$ & $\begin{array}{l}\text { Uninsured } \\
\text { poor } \\
\text { individuals } \\
(15 \%)\end{array}$ & $\begin{array}{l}\text { Inpatient and ambulatory } \\
\text { care, pharmaceuticals }\end{array}$ & $\begin{array}{l}\text { General budget } \\
(100 \%)\end{array}$ & $\begin{array}{l}\text { Attached to } \\
\text { the Ministry } \\
\text { of Finance } \\
\text { through the } \\
\text { Ministry of } \\
\text { Health, will } \\
\text { be } \\
\text { transferred } \\
\text { to the } \\
\text { Social } \\
\text { Security } \\
\text { Institution } \\
\text { by the end } \\
\text { of } 2012\end{array}$ \\
\hline $\begin{array}{l}\text { After } \\
\text { merging }\end{array}$ & $\begin{array}{l}\text { General } \\
\text { Health } \\
\text { Insurance } \\
\text { scheme, } 2006\end{array}$ & $\begin{array}{l}\text { Turkish } \\
\text { citizens, } \\
\text { refugees, } \\
\text { foreigners } \\
\text { residing in } \\
\text { Turkey for } \\
\text { more than } 1 \\
\text { year }\end{array}$ & $\begin{array}{l}\text { (1) Primary care, } \\
\text { rehabilitation, preventive } \\
\text { services; (2) ambulatory } \\
\text { and inpatient care; (3) } \\
\text { maternal benefits as well as } \\
\text { in vitro fertilization } \\
\text { treatment; (4) partial } \\
\text { general oral and dental } \\
\text { care; (5) blood and blood } \\
\text { products, bone marrow, } \\
\text { vaccination, medicine, } \\
\text { medical devices and } \\
\text { equipment }\end{array}$ & $\begin{array}{l}12.5 \% \text { of a } \\
\text { person's gross } \\
\text { income, and } \\
\text { employee (5\%), } \\
\text { and employer } \\
\text { ( } 7.5 \% \text { ) salary } \\
\text { deductions. The } \\
\text { rate for people } \\
\text { who are only } \\
\text { dependent on } \\
\text { GHIS is } 12 \% \text { of } \\
\text { their earnings. } \\
\text { The contribution } \\
\text { of the state } \\
\text { will be } 3 \% \text { of } \\
\text { insured earnings } \\
\text { as the basis for } \\
\text { premiums }\end{array}$ & $\begin{array}{l}\text { Attached to } \\
\text { the Ministry } \\
\text { of Labour } \\
\text { and Social } \\
\text { Security } \\
\text { through the } \\
\text { Social } \\
\text { Security } \\
\text { Institution }\end{array}$ \\
\hline
\end{tabular}

\section{Policy objectives: reasons behind moving toward merging of insurance funds}

The health financing system of Turkey experienced serious problems in the late 1990s and early 2000s. The first issue was related to insufficient and inequitable financing in the health system. Until 1990, 
nearly $3.8 \%$ of the GDP was allocated to the health system, which was much lower than the OECD and other European countries with similar revenue (7.4\%). Low health costs had combined with an unjust and fragmented insurance system. The five existing insurance schemes had various services packages and different contractual arrangements with health care service providers, which had led to inefficiency and inequity in the health system. Despite being insured, some people had difficulty in accessing services due to a sever lack of human resources in the health sector. Different contribution rates, benefit packages with different range and depth of services, various access rules and privileges among different insurance schemes along with organizational fragmentation had created significant disparities in the quality and accessibility of insurance services ${ }^{33}(4)$. This led to structural reform of health insurance system in Turkey as a masterpiece of the Health Transformation Plan in 2003.

\section{Process of merging:}

In 2006, a single system titled "the General Health Insurance Scheme (GHIS)" was established within the Ministry of Labor and Social Security, to merge all existing health funds including the Social Insurance Organization, the Social Insurance Agency of Merchants, Artisans and the Self-Employed, and the Government Employees Retirement Fund under one umbrella, "Social Security Institution" 33,35-37.

In 2006, the Grand Assembly ratified the Social Insurance and the General Health Insurance Law to bring together the five health insurance schemes within a unified General Health Insurance scheme. The Turkish Medical Association, medical professionals unions and the Republican People's Party opposed the law in the constitutional court. In light of pending presidential and general elections, the government postponed the enforcement of the law until 1 October 2008. Before implementation of the law in 2008, it was modified three times and three schemes including the Social Insurance Organisation, Bağ-Kur, and the Government Employees Retirement Fund were transferred to the Social Security Institution. In the next step, the Active Civil Servants Health Insurance Scheme in January 2010 and the Green Card scheme in 2012 were transferred to the Social Security Institution respectively ${ }^{12,33,38}$.

Through the HTP in Turkey, synchronizing the health benefits and coverage across the different health insurance schemes including Green Card began even before establishment of the Social Security Institution. In 2005, Green Card holders were given access to outpatient care and pharmaceuticals and Social Insurance Organization beneficiaries were given access to all public hospitals and pharmacies ${ }^{33}$. In 2006, the pharmaceutical positive list was integrated across all health insurance schemes, including that of Green Card holders ${ }^{33}$. In 2007, legislative measures mandated that all Turkish citizens would have access to free primary care, even if were not covered under the social security system. Under the Health Implementation Decree of 2007 (Resmi Gazete, 2007), benefits across the formal health insurance schemes were further harmonized ${ }^{33,38}$. The enforcement of the GHIS law in October 2008 has completed the harmonization of the benefits package. In 2007, a new system called MEDULA was introduced to standardize and unify the process of claim and utilization management across all the health insurance funds ${ }^{33}$. 


\section{Facilitators of merging:}

\section{Leadership and Political commitment:}

In Turkey, the political stability which was achieved by the Turkish government and enjoyed the support of the majority of the Grand National Assembly was an important factor in health reforms and evolution. The Grand National Assembly managed to pass the laws which were proposed by the government, unlike the federal governments which were unable to implement policies for many years. A committed transformation team in the ministry of health, prime minister's firm support of reform, leadership and persistence of the minister of health, and great management created the necessary conditions for implementing the laws which were passed by the Grand National Assembly. This team, which enjoyed the support of the prime minister and the cabinet, operated constantly for more than ten years ${ }^{12}$.

\section{Formation of a research team, training workshop and executive program:}

In Turkey too, the main reason of success of HTP and HUC was the transformation team - very committed transformation team which consisted of people working together for ten years from 2003 to 2013. The transformation team had an active role in understanding, designing, implementing and monitoring the HTP, and provided strategic orientation, continuity, and institutional memory for transformation. The team worked with international agencies and experts, and provided the connection between strategic and operational phases of the implementation. Regular surveys of field conditions formed strong connection channels between the provincial leadership, local implementation teams, and the Ministry of Public Health. Another success factor of the HTP was the speed of policy implementation. As soon as a decision was made or a law was passed, it was implemented according to the time table which was monitored weekly by the transformation team. Whenever there was a delay, the implementation strategies were changed and local groups or special teams of the Ministry of Public Health were tasked with identifying bottlenecks. These quick implementations prevented organized resistance against reforms, and helped overcoming bureaucratic resistances. The speed of implementation was legitimized by a quick explanation of benefits for users and the public ${ }^{12}$.

\section{Informing people, focusing on consumer satisfaction and acceptance of the change by the people:}

In Turkey, the transformation team assessed the acceptability of changes made by HTP across different groups of people, through establishing focus groups and analyzing beneficiaries. The findings of the focus groups and beneficiary analyses were used to redefine the range of HTP, inform the public, and speed up the process of implementing the program. Beside the focus group researches and stakeholder analyses, annual household surveys were conducted by the Turkish Statistical Institute. The surveys introduced an index for measuring people's level of satisfaction and their reaction to the reforms announced by different ministries ${ }^{12}$.

Informing people, focusing on consumer satisfaction and acceptance of the change by the people: 
In Turkey, the transformation team assessed the acceptability of changes made by HTP across different groups of people, through establishing focus groups and analyzing beneficiaries. The findings of the focus groups and beneficiary analyses were used to redefine the range of HTP, inform the public, and speed up the process of implementing the program. Beside the focus group researches and stakeholder analyses, annual household surveys were conducted by the Turkish Statistical Institute. The surveys introduced an index for measuring people's level of satisfaction and their reaction to the reforms announced by different ministries ${ }^{12}$.

\section{Economic growth and stability and financial feasibility:}

Like South Korea, in Turkey, the economic stability and fast growth of GDP, which occurred between 2003 and 2012, provided the required financial capacity, enabling the government to invest in social affairs. As economic growth increased, the government increased the health budget and investment in the health sector. Also, the investments of the private sector in health were increasing. Along with the stable growth of GDP, new laws and methods improved tax collection, and balanced economic policies increased tax collection and decreased inflation and unemployment rates. Increased tax revenues of the government, encouraging privatization and foreign investments enabled the government to expand the coverage of the Green Card using the public budget revenues and establish the universal public health insurance ${ }^{12}$.

\section{A comprehensive strategy based on evidence:}

The HTP scheme in Turkey was devised based on the evidence and experience of other countries such as Belgium, Cuba, Denmark, Estonia, Finland, Mexico, Thailand, and England. The Ministry of Health successfully benefited from the cooperation of international agencies and national and international experts. Along with international experience, local experience and studies related to the coverage and efficiency of the health sector and obstacles ahead of the health system of Turkey were used ${ }^{12}$.

Other factors that facilitated the merger of insurances as a part of the Health Transformation Plan in Turkey included creating a receptive environment, considering health as the fundamental right of people, constant learning and monitoring of the programs, and flexible implementation ${ }^{12}$.

\section{The resistances and limitations ahead of the merger:}

\section{Concerns about inconsistency between merger law and national laws such as constitutions:}

In Turkey, although the law of the General Health Insurance Scheme (GHIS) was approved by the Turkish Grand National Assembly on May 31, 2006, and it was expected to be implemented on January 1, 2007, the opposing party (the Republican People's Party) claimed that the law was against the constitution. This law faced the opposition of the Turkish Medical Association and other professional medical unions, and was challenged in the constitutional court. The law was revised three times before its implementation. The government postponed the enactment date until July 1, 2007 in order to make the necessary changes. In the light of the presidential and general elections, politicians convinced the 
government to further postpone the implementation until January 1,2008. The final revised version of the law was enacted on April 17, 2008 and implemented on October 1, 2008 ${ }^{37}$.

\section{The merging policy positive consequences:}

\section{Improving equity in health financial and health care utilization}

Merging has been successful in improving health financing equity as, out-of-pocket share in Turkey was $19 \%$ of the total health costs three years after the implementation of the program, which was considered fairly low ${ }^{39}$. By implementing GHIS nearly all population are now under health insurance coverage. Studies show that introduction of GHIS has improved both financial protection against high health expenditures, and equity in access to health care across the population and has made health financing more progressive as richer households pay more of their spending for the health than poorer families. The studies also indicate highest reduction in out-of-pocket spending in Turkey among OECD countries between 2000 and 2012and reducing OOP payments among the poor as a result of extending Green Card Coverage $32,33,40,41$.

\section{Creating a single information bank and removing the coverage duplication}

Before the General Health Insurance Scheme (GHIS) in Turkey, different statistics were presented by different information system for health insurance population coverage statistics, ranging from $67.2 \%$ to $84.5 \%$. In one case $101.15 \%$ was reported. These differences were result of lack of single information system. The Organization for Economic Co-operation and Development of Turkey reported that many people have more than one insurance policy, which leads to duplication and an increase in the number of the insured records ${ }^{37}$.

\section{The probable risk and negative consequences of merging:}

\section{Need for more financial support by the government}

One issue that must be considered while merging insurance funds is that the long-term financing of the single fund must be guaranteed. In Turkey, the health system's share of GDP quickly increased form 5.4\% in 2000 to $6.7 \%$ in 2009 . This number was constant in 2010 and $2011^{12}$. Critics expressed their concerns about the probability of increasing the financial engagement of the government by implementing universal health coverage as they believed that unemployment makes it difficult to collect premiums and the government have to pay instead of them ${ }^{34}$.

\section{Other contributing health reforms alongside merging:}

In Turkey, alongside merging health insurance funds, new roles were defined for the Ministry of Health in a way to enhance the stewardship role, and assigning executive (operational) responsibilities to new organizations ${ }^{12}$. Between 2003 and 2010, during which the Ministry of Health was responsible for the management of the hospitals which were affiliated with the Social Security Organization and the Green 
Card Program, the role of the ministry was emphasized. Also, after the announcement of the law of the reorganization of the Ministry of Health and the autonomy of hospitals, the ministry of health focused on devising strategies and policies, assessing the performance of the health system, and monitoring the responsiveness and inter-divisional coordination. The executive responsibilities related to public health, concluding contracts, providing health services, and assessing health technologies were assigned to new quasi-governmental organizations. After the introduction of the uniform public health insurance, the Social Security Organization took over the management of the Green Card Program ${ }^{12}$.

Another structural reform was the transformation of the hospitals of Turkey. Public hospitals such as hospitals of the Social Security Organization which were not being managed by universities or military organizations were transferred to the Ministry of Health in 2005 under the Health Transformation Program (HTP). The apparent reason for this action was to ensure uniformity among public health providers in terms of service quality; however, the subtle motivation was to improve the process of transferring hospitals to local governments which was considered within the framework of public administration reforms ${ }^{37}$.

Along with other reforms, the health transformation plan conducted four new key programs in the human resources department in order to emphasize the problems related to the shortage of human resources in the health system. The first program was implemented to increase the number of schools and colleges for medicine, nursing, midwifery and other related fields. The second program included a raise in wages and incentives based on performance for hospitals and primary health care centers, and the possibility for constant salary rise for healthcare employees. The third program focused on concluding new contracts with the health employees and purchasing services from the private sector. And finally, the fourth program was the law of prohibiting dual practice for physicians, which was passed in 2010. Based on this law, the physicians who were not employed by the Ministry of Health had to work full time in government hospitals. Also, they were banned from working in the private sector at the same time ${ }^{37}$.

\section{Emphasizing on primary health care services}

In 2005, the health transformation plan in Turkey introduced a family physician-centered primary care model and emphasized on increasing resources in three areas - physical resources, human resources, and creating capacity for human resources. Based on this model, each family physician provided services more than what was provided in rural health center or health centers, to a population of 4000 people. After 2005, about 20000 family physician teams were formed. The existing infrastructures were improved and most rural health centers and health centers were kept or merged with family physician centers. Until 2011 , nearly 6250 new family physician centers were founded ${ }^{12}$.

\section{Future Challenges:}

In Turkey the main current challenge is keeping the universal health insurance financially sustainable as the health expenditures are going up due to the comprehensive scope of Turkey's UHI, changing 
demographics and various economic indicators ${ }^{33}$. So it is said that Turkey should address two policies, finding new funds and focusing on cost containing measures. Identifying the informal sector workers who do not report their real income or those workers that have not registered in the labor force and levy tax on them have been mentioned as potential solutions to generate new financial resources. The following measures have been advised to curb the total health care expenditures: narrowing the benefit package under coverage of GHIS as it is considered so extensive, moving towards bundled payment methods like DRG, updating and contracting the list of pharmaceuticals, setting new copayments and coinsurance rates, emphasizing on primary health care and introducing gate keeping role and implementing referral system into family physician program to manage the flow of patients through the health system, and forcing the public hospitals to be autonomous and manage themselves on their own $^{33}$.

\section{Thailand}

\section{Health insurance system in Thailand before and after the merging:}

In Thailand, the structure of insurances before the merger was as follows: The Medical Welfare Scheme: It was a free program covering the elderly (older than 60 ) and children under 12, the disabled, monks, religious leaders, and veterans. Also, there was the Civil Servant Medical Benefit Scheme (CSMBS) which covered government employees and retirees, of government enterprise employees and retirees, and family members. This scheme is considered the most generous insurance scheme in the country. The other scheme is the Social Security Scheme (SSS) which was established to cover the illnesses and injuries of the private sector employees (but not their dependents). The Voluntary Health Card Scheme (VHCS) was the continuance of a community financing initiative of 1983 which started as a scheme for covering the workers of the informal sector ${ }^{30,42-44}$. More information about Thailand health insurance system has been provided in Table 4.

Table 4: Social health insurance structure in Thailand before and after the merger 


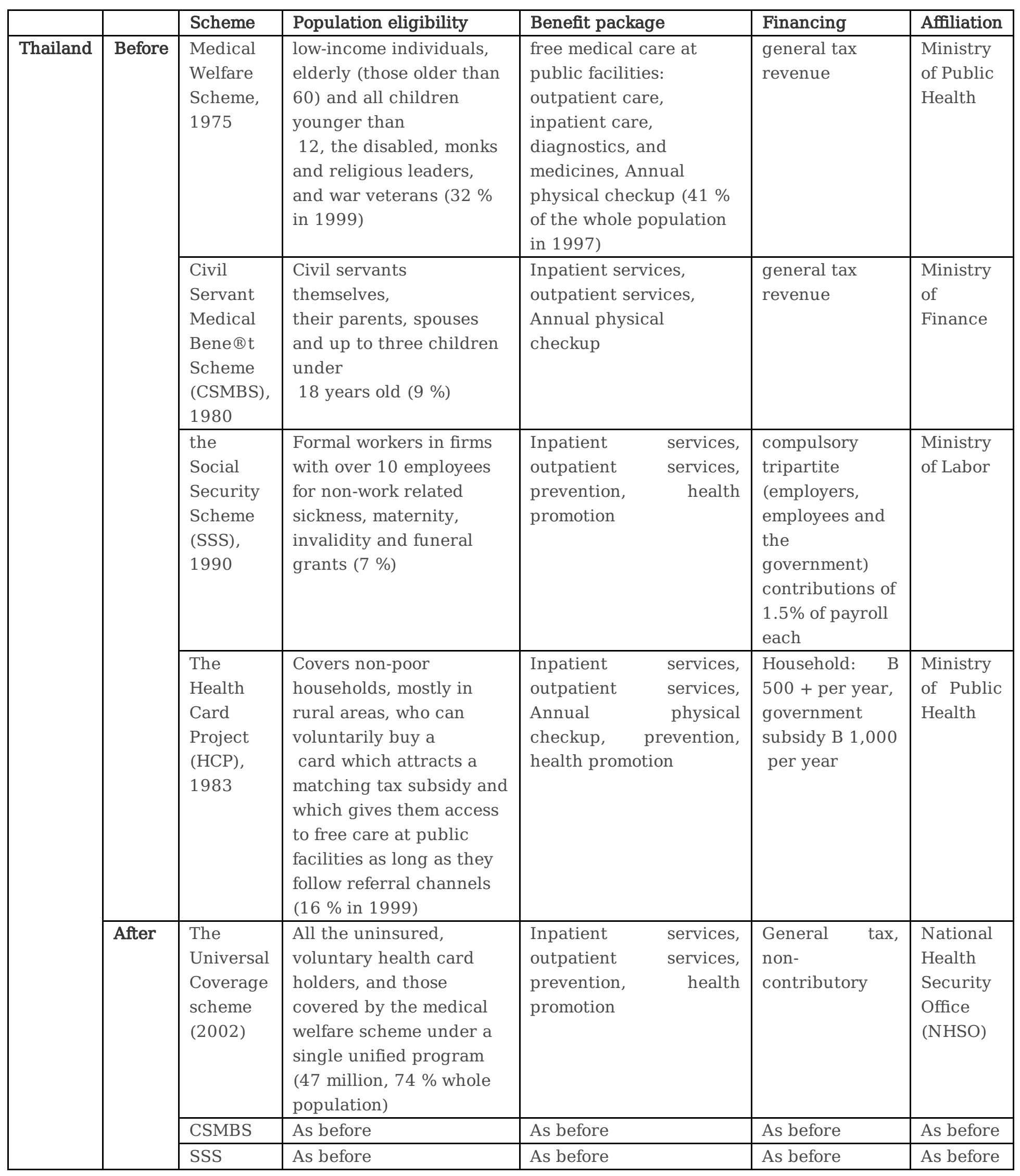




\section{Policy objectives: Reasons behind moving toward merging of insurance funds}

In Thailand, each health insurance scheme had its own specific rules, regulations and benefit packages for its own beneficiaries. The uninsured had to pay high prices in governmental health centers or choose private centers. A low number of people had private insurances. These funds were different in terms of size of population overage, the definition of eligibility, benefit package, payment method, financial resources, per capita expenditures, and subsidy. Each of these schemes covered different parts of the population and had different methods of reimbursement and gaining revenue. Improper and inequitable distribution of government subsidies across the aforementioned insurance schemes had extremely affected the productivity level and benefits of each scheme $e^{45,46}$. About $70 \%$ of the population was under the coverage of the four public health insurance schemes, while private insurance played almost no role. The remaining $30 \%$, more than 15 million people, were not covered by any medical insurance and had to pay out-of-pocket for health care services and medicine ${ }^{30,43}$. Inefficiency was prominent in almost all of the schemes due to various reasons such as adverse selection, moral hazards, and allocative inefficiency ${ }^{30}$. All of these problems made the Thailand government to merge health insurance schemes in 2002 as a solution to solve above challenges.

\section{Process of merging:}

The three main insurance schemes of Thailand after merging are the Universal Coverage scheme, the CSMBS under the administration of the ministry of Finance, and the Social Security scheme under the administration of the Social Security Organization. The Universal Coverage scheme covered all the uninsured, voluntary health card holders, and those covered by the medical welfare scheme under a single unified program ${ }^{30,43}$.

\section{Facilitators of merging:}

\section{Leadership and Political commitment:}

In Thailand, universal coverage was considered as an important national issue by the Thai Rak - a new political party created by the richest capitalist in Thailand, Thaksin Shinawa. This scheme was a key part of this party for the election of 2001. The leaders of this party considered a policy for achieving universal coverage due to its intrinsic popularity, financial feasibility and technical achievability according to the studies ${ }^{30}$.

\section{Formation of a research team, training workshop and executive program:}

In Thailand, the Working Committee on Universal Coverage was formed in 2000 with the support from the Health Systems Research Institute. After winning the election, the universal coverage policy was included in the government's policy and immediately, a workshop on the issue of implementing universal coverage was organized by the prime minister. Also, a task force was established for the purpose of the implementation of the universal coverage program, and the Ministry of Public Health was tasked with the 
implementation of the program. With several members of the Labor Committee present in this workshop and in the task force, the program was implemented exactly according to the recommendations of the committee members ${ }^{30}$.

\section{Informing people, focusing on consumer satisfaction and acceptance of the change by the people:}

In Thailand, the media played an effective role in keeping people informed, and was active in informing people of different subjects of the universal coverage and consequently increasing people's awareness ${ }^{30}$.

\section{Economic growth and stability and financial feasibility:}

In Thailand, in accordance with the spirit of the 1997 constitution, the Universal Coverage Committee was established in $\mathbf{2 0 0 0}$ to assess the potential alternatives for the universal coverage. This committee studied and confirmed the financial feasibility of achieving universal coverage and stated that assuming an efficient insurance system, it can be affordable. In total, B 100 billion was predicted for the universal coverage per year, which was not much higher than the $\mathrm{B} 76$ billion which was spent annually by different health insurance schemes and the public health budget at that time ${ }^{30}$. Thailand committed itself to expanding coverage under the Universal Coverage Scheme (UCS) in 2002, after the Asian financial crisis when macroeconomic growth prospects were still fragile. However, economic growth has been one of the important enabling factors underpinning the subsequent expansion of UHC in many countries once they adopted $\mathrm{UHC}^{15}$.

\section{Comprehensive information system:}

In Thailand, the first problem was to identify the uninsured (those who were not covered by SSS or CSMBS) considering the fact that there was no database of CSMBS beneficiaries available. Consequently, a comprehensive information system was quickly established using a government registration database to avoid the duplication of health insurance benefits. This was not an easy task since more than 50 million records had to be created ${ }^{30}$. Reliable information system in place made the following activities easier which are vital for reaching UHC: assigning a unique citizen ID number to each citizen, identifying members of the UCS and register them with a preferred provider network, dynamic and automatic transferring of members between the three public insurance schemes by changing their eligibility criteria ${ }^{43}$.

\section{The resistances and limitations ahead of the merger:}

\section{Opposition aroused by population groups enjoying better benefit package:}

One of the most important challenges and resistances facing of the merger of the funds is the objection of insurances with more generous packages, especially when the single insurance is affected by the low performance in the past, and understanding of low quality benefit packages due to insufficient premium level $^{28}$. In many countries, there are different schemes for government employees, private sector staff, 
and the self-employed, and each has its specific benefit package. For instance, in Thailand, government employees use a more generous benefit package. Equalization of benefit packages for all funds will face oppositions from stronger funds ${ }^{22}$. In Thailand, the labor unions were concerned about the transferring of budget from the Social Security Fund to the Universal Coverage scheme, and considered the benefits of the Universal Coverage to be lower than what they already had. The unions organized several street protests to demonstrate their concerns against the merger of the Social Security scheme with the Universal Coverage Scheme ${ }^{30}$.

Using public hospitals and health care centers by the members of health insurance with poor packages and financing can cause distrust among those who enjoy currently high quality health services in private sector financed by strong and private insurance. Private employees may think that the single insurance provides low-quality health care which is currently provided for the members of weak insurance schemes. In order to solve this problem, it is better that the single insurance scheme focus on those who are not under coverage of any fund fist. Gradually, the compulsory insurance fund should improve the quality of its services while simultaneously proving that it is possible to provide high-quality services with lower prices and contribution rates than private health insurance ${ }^{28}$. The differences in benefit packages across health insurance funds will lead to social classification and in turn portability problems between various funds, especially when migration rates from rural areas to urban areas are high.

\section{Concerns of workers and employers about increase in contribution rates:}

In Thailand, a strong opposition was formed by the members of the Social Security Scheme (SSS), especially labor unions, against the expansion of SSS to other groups, because they feared that the SSS'S resources would be used as subsidy for the rest of the population. The Social Security Office was concerned about the actuarial feasibility and the limited support from the employers ${ }^{47}$.

In Thailand, the Medical Association supported the Universal Coverage Bill but showed opposition to the medical responsibility clause included in the bill. The Medical Association was concerned about the increase in the purchasing power of single national insurance scheme ${ }^{12}$.

\section{Concerns about the monopsonistic purchaser power of NHSO}

Providers were against applying bundled payment methods such as capitation and diagnostic-related groups under global budget something that it is hoped to be implemented by having a strong insurance scheme. Strategic purchasing of the NHSO was not welcomed both with hospitals and pharmaceutical companies as hospital preferred to purchases medical devices on their own and pharmaceutical companies could earn higher benefits by selling directly to hospitals rather than to the $\mathrm{NHSO}^{43}$.

\section{The merging policy positive consequences:}

\section{Reaching universal health coverage and leaving no one behind}


Normally, one of the consequences of the multiple insurances is that despite existing different health insurance organizations alongside each other, a part of the populations is not covered by any insurance for different reasons. Achieving universal coverage can be considered as one of the advantages of merging insurance funds. In 2002, Thailand achieved universal coverage through a strong government with political commitment, supported by civil society and great knowledge, and in 2014 , nearly $99 \%$ of the population were under coverage.

\section{Improving health financing equity}

Apart from improving access to outpatient care and hospital admissions especially among elderly people, UCS have been successful in improving financial indicators for instance the household out-of-pocket payments have been reduced from 34\% of total health expenditure in 2000 (before the UCS) to $12 \%$ of total health expenditure in 2014. It also has reduced chance of facing catastrophic and impoverishing health care expenditures ${ }^{43}$.

\section{Other contributing health reforms alongside merging:}

In Thailand, the wide geographical coverage of health care facilities of the Ministry of Public Health $(\mathrm{MOPH})$ was an important foundation for the implementation of the universal coverage scheme. This meant that the members of the scheme - many of whom were living in rural areas - had access to the services. In 1970, Thailand began to build more hospitals and train more nurses and doctors, and as a consequence, the ratio of the population to beds, nurses, and doctors was significantly improved by 1990 48 .

\section{Emphasizing on primary health care services}

In Thailand, the Universal Coverage scheme, aiming to provide equal access to health care for all, has three defined characteristics focusing on the constraining total health care expenditures: UHC scheme is financed by taxation providing free-of-charge services, a comprehensive service package focusing on primary health care such as prevention of illnesses and improving the health status, and using fixed capped budget to reimburse provider ${ }^{48}$.

In Thailand, the Universal Coverage program is trying to use financial mechanisms to improve primary health care. The main financial resource of the Universal Coverage scheme is the taxation revenue which is paid annually by the government per person (1899 baht per person in 2007). This amount is directly paid to the providers that have a contract as per capita 42,49 .

\section{The purchaser-provider split:}

One of the significant innovations was done on a parallel with introducing UHC scheme was the establishment of the National Health Security Office (NHSO) in Thailand to act as a purchasing agency for the beneficiaries of the Universal Coverage scheme. In fact, the purpose was to separate the purchaser 
from the provider. This meant that the Ministry of Public Health will not have much control over the government expenses related to the public health services ${ }^{48}$.

The NHSO was established as a quasi-government organization with the minister of public health as the head of its executive board. Operation and management of the Universal Coverage scheme fund was transferred from the Ministry of Health to the NHSO as the purchaser of health care for the members of the Universal Coverage Scheme ${ }^{30}$.

\section{Need for moving towards closeended payment methods}

In Thailand another significant reform was change of the payment method. In the UHC insurance scheme, payment for outpatient services is in form of capitation and the government pays this capitation to the contracted centers, based on the number of people who are registered in these centers. The amount of this capitation is calculated annually. For hospital services, the employed method is based on diagnosticrelated groups. Also, prevention and health promotion services are included in the basic package, and the method of payment to providers is based on the capitation system along with the performance-based payment ${ }^{50}$. This made it easier to project the total funding needs to manage the UHC insurance and assessment of financial feasibility 43 .

\section{Future challenges:}

The harmonization of the three government health insurance schemes is still the focal point of debate after the beginning of the universal coverage in Thailand. Inequality between these three schemes has challenged the right to public health care as the right to access health care with equal standards for all the people of Thailand. Recent studies showed that harmonization between UCS and social health insurance has been achieved in terms of benefit package and applying closed-end provider payment methods but there are still problems with CSMBS. CSMBS uses fee-for-service for out-patient care and uses different bands of DRG payments for in-patient services in a way which favor tertiary and teaching hospital over other hospital leading to quadruple per capita expenditures in CSMBS compared to uCs $^{43,47,48}$.

\section{Indonesia}

\section{Health insurance system in Indonesia before and after the merging:}

In Indonesia, the structure of insurance included the following organization before the merger: 1- Civil Servant Social Health Insurance Scheme (Askes), which covered all government employees and retirees and military personnel. 2- The Private Employee Social Health Insurance Scheme (Jamsostek). 3- The Commercial Health Insurance scheme JPKM (HMOs), which is entirely similar to the Health Maintenance Organization (HMO) of the US. The JPKM insurance is classified under commercial insurance, and provides in kind benefits which are managed by various managed care organizations that are not insurance companies. Several Social Safety Net schemes have been introduced over recent decades to 
assure the poor's access to necessary health services with different level if success. The last program to cover the poor were Jamkesmas and Jamkesda that were provided by national and regional governments respectively ${ }^{28,51-53}$ Details of the health insurance schemes are presented in Table 5.

Table 5: Social health insurance structure in Indonesia before and after the merger 


\begin{tabular}{|c|c|c|c|c|c|c|}
\hline & & Scheme & $\begin{array}{l}\text { Population } \\
\text { eligibility }\end{array}$ & Benefit package & Financing & Affiliation \\
\hline \multirow[t]{6}{*}{ Indonesia } & \multirow[t]{4}{*}{ Before } & $\begin{array}{l}\text { Civil Servant } \\
\text { Social Health } \\
\text { Insurance Scheme } \\
\text { (Askes), } 1968\end{array}$ & $\begin{array}{l}\text { All civil } \\
\text { servants } \\
\text { and } \\
\text { pensioners } \\
\text { of civil } \\
\text { servants } \\
\text { and } \\
\text { military } \\
\text { personnel }\end{array}$ & $\begin{array}{l}\text { All members } \\
\text { entitle to } \\
\quad \text { comprehensive } \\
\text { benefits } \\
\text { considered } \\
\text { medically } \\
\text { necessary }\end{array}$ & $\begin{array}{l}2 \% \text { of their basic } \\
\text { monthly salary, } \\
\text { regardless of their } \\
\text { marital or family } \\
\text { status }\end{array}$ & $\begin{array}{ll}\text { State } & \text { own } \\
\text { company } & \end{array}$ \\
\hline & & Jamsostek, 1992 & $\begin{array}{l}\text { Social } \\
\text { Health } \\
\text { Insurance } \\
\text { Scheme for } \\
\text { Private } \\
\text { Employee }\end{array}$ & $\begin{array}{l}\text { The benefits are } \\
\text { in kind, } \\
\text { through various } \\
\text { health care } \\
\text { providers } \\
\text { contracted. } \\
\text { Other Jamsostek } \\
\text { programs pay } \\
\text { cash benefits to } \\
\text { the } \\
\text { beneficiaries. }\end{array}$ & \begin{tabular}{lrr}
\multicolumn{3}{c}{ Only employers } \\
\multicolumn{2}{c}{ are mandated to pay } \\
premium of & $3 \%$ \\
(singles) and & $6 \%$ \\
(married) & & of \\
employees & &
\end{tabular} & --------- \\
\hline & & $\begin{array}{l}\text { Commercial } \\
\text { Health Insurance }\end{array}$ & $\begin{array}{l}\text { They are } \\
\text { actually } \\
\text { non } \\
\text { insurance } \\
\text { companies } \\
\text { selling } \\
\text { health } \\
\text { insurance } \\
\text { to }\end{array}$ & $\begin{array}{l}\text { comprehensive } \\
\text { health services }\end{array}$ & ----- & $\begin{array}{l}\text { Run by the } \\
\text { owner }\end{array}$ \\
\hline & & $\begin{array}{l}\text { Jamkesmas (by } \\
\text { national } \\
\text { government), } 2008\end{array}$ & $\begin{array}{l}\text { Poor } \\
\text { people }\end{array}$ & $\begin{array}{l}\text { Providing } \\
\text { different block } \\
\text { grants } \\
\text { financial } \\
\text { assistance for } \\
\text { poor family to } \\
\text { access health } \\
\text { care services }\end{array}$ & Public budget & \\
\hline & & $\begin{array}{l}\text { Jamkesda (by } \\
\text { regional } \\
\text { government), } \\
2008\end{array}$ & $\begin{array}{l}\text { Poor } \\
\text { people }\end{array}$ & $\begin{array}{l}\text { Providing } \\
\text { different block } \\
\text { grants } \\
\text { financial } \\
\text { assistance for } \\
\text { poor family to } \\
\text { access health } \\
\text { care services }\end{array}$ & Public budget & \\
\hline & After & $\begin{array}{l}\text { national health } \\
\text { insurance } \\
\text { programme } \\
\text { (BPJS), } 2014\end{array}$ & All citizens & $\begin{array}{l}\text { comprehensive } \\
\text { basic benefit } \\
\text { package, } \\
\text { outpatient and } \\
\text { inpatient care at }\end{array}$ & $\begin{array}{l}5 \% \text { of salary of } \\
\text { salaried } \\
\text { workers and their } \\
\text { family } \\
\text { members (Employers, }\end{array}$ & $\begin{array}{l}\text { National Social } \\
\text { Security } \\
\text { Agency (Badan } \\
\text { Penyelenggara } \\
\text { Jaminan Sosial }\end{array}$ \\
\hline
\end{tabular}




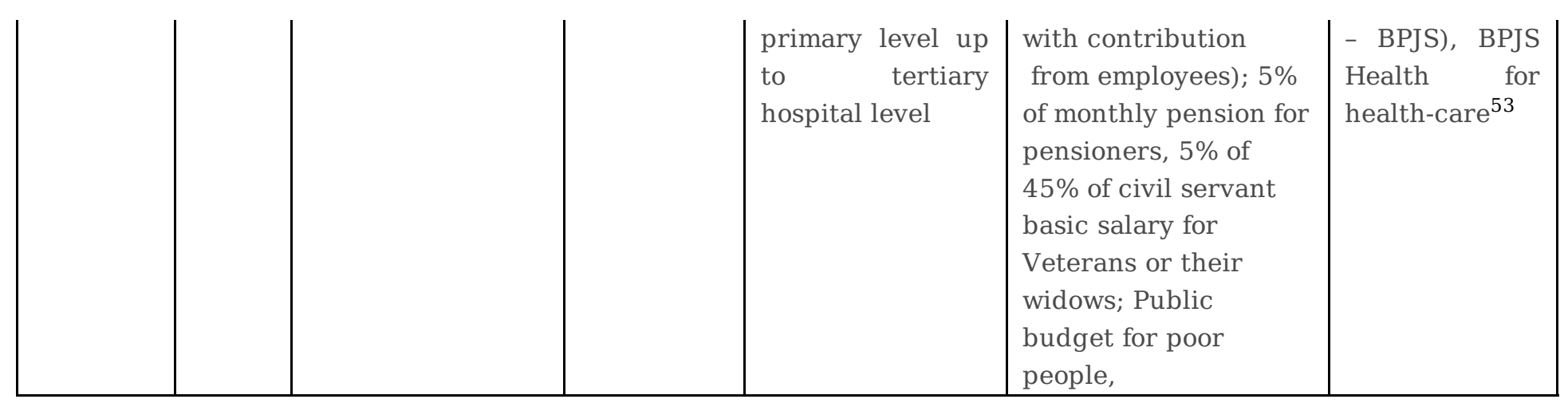

\section{Policy objectives: Reasons behind moving toward merging of insurance funds}

In Indonesia, the health insurance system was far from just due to improper implementation. For government employees, the payment rates of the social health insurance to hospitals were much lower than governmental medical tariffs. Financial support for the poor and vulnerable groups such as pregnant mothers, children under five and the elderly was seriously insufficient (16). Different programs to cover the poor suffered from underutilization and were not precise to target the real poor people and other people than the poor used these programs. Poor people were not able to use cards due to lack of understanding, stigma of being perceived as poor, living in remote areas and lack of public facilities. Therefore, in November 2011, Indonesia enacted an ambitious act which forced the five government insurance funds, which had covered different parts of the population, to merge into a universal program in order to reach cross subsidies, reduce administrative costs, providing the same benefit packages for all, and reduce inequities in access to the benefit packages $(8)^{52}$.

\section{Process of merging:}

In November 2011, a new law was passed mandating BPJS, the 'Social Security Administering Body'. The National Social Security Council was established to address the law. The council created two social security corporations including the Social Security Agency for Health as a non-profit trust fund called BPJS Health, while the workplace insurer JAMSOSTEK was assigned to administer pensions, life and workplace insurance as its new mission called, BPJS Workforce. Assets, liabilities, participants and staff of the corporations were automatically transferred to the new bodies. BPJS Health began to operate in January 2014 and integrated the previous existing health insurance fund including Askes, Jamsostek, Jamkesmas, Jamkesda and also military personnel (Asabri). The premiums for the poor would continue to be paid by the state. BPJS would operate as a single quasi-government entity. It uses a prospective payment methods including capitation for primary care providers and Diagnosis Related group (DRG) on the basis of Indonesian case-based groups for secondary health providers. It is worth mention that participating in the BPJS is mandatory and employers are not allowed to opt out of BPJS ${ }^{53-55}$. 
According to the Roadmap of National Health Insurance, it is supposed that all Indonesian citizens will be covered by the BPJS Health by January $2019 .{ }^{53}$ By October 2018, 203 million people forming $75.88 \%$ of the whole population were covered by BPJS ${ }^{55}$.

\section{Facilitators of Merging:}

\section{Leadership and Political commitment:}

In 1999, Indonesians elected PDI-P party led by Megawati Sukarnoputri who had campaigned to work on equity. In 2000, the new parliament included the "right to receive medical services" in the 1945 constitution and again later on the state was obliged by the constitution to ensure providing health service as well as developing a social security system for all citizens. PDI-P leader Megawati, then VicePresident assigned a working group of over 60 people to draft the social security law. In its first version, the integration of all four state-owned insurance firms into a single entity was specified to operate as a single payer, not-for-profit trust fund. According to the reports, the bill of social security reform was revised 56 times before submitting to the parliament in January $2004^{54,55}$. Although by changing the President and taking the office by the next President, Yudhoyono, policy agenda changed and social security reform was put aside for the next ten years until it was came into effect in $2014^{55}$.

\section{The resistances and limitations ahead of the merger:}

\section{Concerns of workers and employers about increase in contribution rates:}

In Indonesia, the private sector employers may refuse to join the National Health Insurance since they are afraid that the contribution rates might increase partly because they could no longer opt out of the staterun scheme. They also argued that the mandatory schemes violated human rights. Also the current competitive market may oppose formation of any kind of mandatory health insurance ${ }^{28,54}$. In, Indonesia, during the passing of the law in the parliament, strong resistance was formed by labor unions and employers' organizations ${ }^{56}$. Also, the Ministry of Labor was against the unified insurance bill. Initially, the Ministry believed that the bill would put more pressure on the workers and that the Ministry might lose control over the social security funds of private employees. Under the social security system before the merger, government employees paid all the contribution themselves, while private sector employees did not make any contribution. The National Health Insurance Bill proposed a shared contribution between employers (government as the employer of government employees) and employees. The private sector employees who did not have any contribution until then, were strongly against the bill. The minister of labor threatened to veto the bill if the shared contribution was approved by the parliament. Even employers' organizations, business offices, and several government authorities rejected the mandatory essence of the Social Security. Employers were concerned about the amount of contribution which would be specified for them. They had some estimation based on their calculations, and opposed bill since they concerned about the probable financial problems that might be imposed by the bill ${ }^{56} .{ }^{54}$

\section{Concerns about sharing benefit package and premiums with underprivileged groups}


Employers worried that premiums paid by workers and employers would be used to subsidise services for the poor and unwaged, leading to a cut in benefits for those in work ${ }^{54}$.

\section{Concerns about losing autonomy and getting exposed to transparency}

Directors of state firms were reluctant to lose their control on their own cash cows and also worried that the restructuring the health insurance system would open their books to public scrutiny ${ }^{54}$.

\section{Need for more financial support by the government}

In Indonesia, the obligation of government as an employer to pay $3 \%$ contribution compared to the currently-paid $0.5 \%$, will require an additional cost of 1.3 trillion rupees annually. Also, obliging the central and local government to pay contribution for the poor will require 5-8 trillion rupees from the central and local budget. The existing financial problems of the government might postpone the coverage of the poor 28 .

\section{Positive consequences of merging:}

\section{Reducing the administrative costs}

Bigger funds will improve the economies of scale, which will in turn maximize the benefits provided for the members. It is estimated that in Indonesia, by implementing the National Health Insurance, similar to the schemes in Taiwan, the Medicare in the US, the Medicare in Australia, the National Health Insurance in Korea and the Philippines, the administrative costs will be reduced to lower than $5 \%$, and can be even further reduced to $3 \%$ of the total $\operatorname{costs}^{28}$.

\section{Equity in benefit package and health care utilization}

The single insurance system can enhance insurance packages and extend the coverage in favor of the poor and the members of weaker insurances. For instance, it is expected that in Indonesia, the uniform service package for civil servants and the private sector employees will create better clarity, equity, and understanding of the package for providers and members ${ }^{28}$.

\section{Creating a single information bank and removing the coverage duplication}

The single insurance system will lead to the concentration of the statistics and information of beneficiaries. In the National Health Insurance of Indonesia, information system and social security number will be unified across all social security schemes using a unique social security number. The uniform information system will reduce the duplication of coverage and membership, and will lead to a higher efficiency and easier transfer of benefits with changing the job in the dynamic labor market ${ }^{28}$.

\section{Paving the way for implementing other contributing health reforms}


Moreover, merging and reducing the number of health insurance funds can create a window of opportunity for implementing extra reforms in the health system. These reforms were less likely to be implemented before due to the multiple insurance schemes working alongside each other. For instance, in Indonesia it is expected that creating a national health insurance scheme with higher number of beneficiaries and higher power of negotiation with the providers increase the chances of implementing per capita payment or other prospective payment methods like DRG. These prospective methods will improve the efficiency of the system. Also, another reform which leads to a higher efficiency of the health system is the better implementation of the family physician program and the referral system. An increase in the number of the insured provides the possibility of using a gatekeeper system and improves the utilization of the family physician as the gatekeeper ${ }^{28}$. One of the challenges of many health systems in human resources is the unbalanced distribution and concentration of providers in big cities. Pooling of funds will improve the equality of the redistribution of providers in all areas. Under a single fund, the money will follow the patient. Currently, about $25 \%$ of all physicians in Indonesia are living and working in Jakarta (Providing services for nearly $8 \%$ of the population) 28 .

\section{Future challenges:}

According to the studies the five major challenges ahead of implementing the BPJS are as follows: the fragmented health financing system, decentralisation, demographic transition, high out-of-pocket spending, and low levels of spending on health by the central government ${ }^{52} 57$. Decentralization of government in Indonesia began in 2011. There are four levels of government including national, provincial, district and sub-district level which have made health financing reform more complicated. There are two parallel programs for covering the poor, the Jamkesda at national level and Jamkesmas which is managed by the regional governments. Jamkesmas began to operate as a part of poor people were not categorized as poor based on the national criteria. Apart from these parallel programs, applying to the national health insurance scheme and running the regional health insurance schemes were problematic for regional governments and also confusing for both providers and patients. Also local governments were obliged to implement all services communicated by the mandatory universal health insurance which is not feasible in some cases ${ }^{52}$.

Membership is another challenge of NHIS. Poor people who are paid by the government dominated the NHIS forming almost $60 \%$ of membership in 2017 which means it put heavy pressure on the public budget. ${ }^{55}$ The second challenge related to the membership is known as "the missing middle for the NHIS". This problem refers to people who work in the informal sector or those who are not living in poverty but are not covered by the NHIS because of low self-enrolment. This population group is typically unwilling to participate in insurance schemes. As this group formed approximately $60 \%$ of Indonesia's labour force in 2014 , low enrolment by this group lingers reaching to universal health coverage and also jeopardize long term financial stability of the NHIS. These problems alongside low coverage of services by the NHIS, high out-of-pocket expenditures (48.3\% of total health expenditures), low average contribution per capita $\$ 30$ in 2016 compared to the average per capita of THE (\$129), budget deficit (the 
claim ratio of average medical cost to average premium collection was $115 \%$ in 2015) means government should inject more public budget into the NHIS and find reliable solutions to rise fund.

To overcome financial issues affecting overall UHC sustainability, four policy options have been suggested: first, increase fees for contributing members, given that current contributions are lower than the costs of medical treatment; second, embrace cost-containment measures, such as soft caps on service volumes; third, improve the health-care reimbursement process by more rigorous medical claim reviews; and fourth, promote efficiency of the NHIS system.

Finally there is need to develop an affordable and appropriate benefits package, expand service provision and encourage the regular payment of premiums by the non-poor, around half of whom do not currently contribute as the law requires ${ }^{54}$.

\section{Discussion}

\section{The role of country context and factors which can influence moving towards merging}

Choosing a health insurance system with single or multiple risk pools depends on the value and importance that are given to the health system goals especially equity and efficiency. So it is unlikely to find a risk pooling model appropriate for all countries even if their socioeconomic conditions are similar. All economic, geographic, cultural, financial, historical and social factors can influence risk pooling approach, that's why different approaches are suitable for different countries. Single or multiple risk pools approach is fundamentally influenced by local considerations. For instance the following items can affect moving towards merging and reducing the number of risk pools: is the health system emphasizing on equity or efficiency?; is universal health coverage is the priority of health system? and which approach, single or multiple risk pools, can help reaching it in a given country?; health financing equity; equity in health service accessibility and utilization; differences in benefit packages among health insurance funds; the role of government in supporting the health insurance schemes financially; the general socioeconomic condition of the country; social solidarity in the society and how much people may prefer the needs of the society than their personal interests; financial sustainability and constraining health care services expenditures; the status quo of administration costs of and also the competition status among health insurance schemes; the degree of autonomy or dependency of health insurance schemes to the public subsidies; the degree of rigidity of governmental regulations which the health insurance schemes have to follow to operate such as modification of benefit package or setting premiums; the possibility of redistributing of risks among risk pools without merging them and etc. For instance, in Thailand, the merger began with schemes under Ministry of Public Health including the Medical Welfare Scheme, VHCS, and those without coverage which were financed mainly by the government. It shows that it is advisable to begin merger from schemes which are governmental, depend on governmental fund or operate under one administration such as ministry of health. Where different schemes belong to different ministries, more cooperation and effort in needed to bring all to an agreement for merging. 
The experience of countries such as Germany and the Netherlands indicates why despite having multiple risk pools, merging health insurance schemes is not the only option to boost the performance of health insurance system. Conversely these countries have encouraged competition among their schemes rather than moving towards merging to increase consumer rights to choose among sickness funds and in turn constrain healthcare expenditures. These countries have launched an equalizer mechanism which allocates a risk-adjusted compensation to insurers with higher risk beneficiaries. This system eliminates a part of health inequity among competitive risk funds. In Germany, competition is preferred than merging as sickness funds don't rely on government subsidy and are autonomous in implementation and management ${ }^{58-61}$. In contrast in Korea, health insurance societies were financed largely by the government subsidy, were not autonomous, and were working within tight regulation framework issued by the government ${ }^{14}$. For this reason merging was a better choice than introducing competition among them.

\section{Potential advantages and disadvantages of merging:}

It is worth to specify that what kind of problems can be solved by consolidation of health insurance schemes in the health system and health financing area and what kinds of challenges may rise as a result of merging that we should be aware of. The clear explanation of potential achievements can be effective on supporting the implementation of the program and reducing the resistances by opposing actors. Apart from advantages and disadvantages that mentioned throughout the article, the following points can also be mentioned as the positive and negative consequences of consolidation according to the experience of the selected countries:

The merger of insurance funds has the benefit of pooling risks across the country ${ }^{14}$ in such a way that pooling all of the people into a single fund maximizes the redistribution of financial burden for health services, which in turn will provide the possibility of cross-subsidy from the rich to the poor, from the young to the old, from the healthy to the sick, and from richer areas to poorer areas of the country ${ }^{28}$.

The international experiences show that the single payer system is more powerful and more efficient in controlling the total health care expenditures ${ }^{14,28}$. Regarding risk pooling efficiency and financial stability, the single payer is more preferable ${ }^{22}$. The collection of contributions will be integrated with other social insurance funds as a result of merging. In the single insurance system, collection of contributions will be much more efficient than the collection of contributions by different health insurance schemes separately in a fragmented system. On the other hand, the more efficient cost management and financial stability of bigger insurance scheme will lead to more stable premiums, and the employers do not need to negotiate with private insurances over the premium and benefits each year. Bargaining with different health insurance funds requires special skills and understanding of the benefits and costs of healthcare services. Therefore, single payer helps the employers focus on their work. On the other hand, the employees do not need to concern about changing insurers over time. Also, the non-profit nature of the single insurance will inject any profit back into services or improvements in packages for the society ${ }^{28}$. 
In addition to the improvement of equity in contributions and reduction of administrative costs, the singlepayer system has more power in bargaining with providers through creating a monopolistic purchaser ${ }^{14}$. The single insurance has the capacity and inclination to purchase medical care cautiously, which will improve the efficiency of the new system ${ }^{14}$. Also, the single insurance system will increase the competition among providers, since the single insurance is the only payer and provides a free choice of providers for the people ${ }^{28}$.

Beside the positive effects, policy reforms like merging health insurance funds together may cause unpredicted side-effects in the health system in the short and long run, which need to be predicted to prevent. A single payer may reduce efficiency due to increasing the bureaucracy and decreasing responsiveness; however, in many developing countries with multiple health insurance schemes where people do not have real right to choose between different funds, the efficiency lost as a result of merging may not be significant ${ }^{14}$. In a single payer system, the insured do not have the chance of choosing and changing the insurer when the health services are not satisfactory which can lead to dissatisfaction, especially in rich families. However, we need to know that the right to choose the provider is much more important and significant than the right to choose the insurer. Insurers are only payers, and have little effect on the process and outcomes of the treatment. In the single payer system, the free choice of the provider and increased competition among providers can increase the satisfaction of the beneficiaries ${ }^{28}$.

Bureaucracy and centralized policy making at a national level may result in mismanagement and reducing the speed of decision making. However, some authority and independency should be delegated from national level to the regional administration in some areas like contractual methods and levels of payments to the providers.

\section{Is merging health insurance schemes enough alone?}

As mentioned before, merging insurance funds and moving from a multiple insurance system towards a single insurance system has various benefits, and based on the level of success in implementation, it may also have side-effects, which need to be rectified. It is worth mentioning that the merger of funds should not be considered as the solution to all health system problems, and we cannot expect a great improvement in the performance of the health system as a result of merger. However, it can be considered as a potential solution in health care financing, and along with other reforms in other health sectors, it can be much more effective due to the synergy that they create together. Therefore, in Turkey, we see that in order to speed up the effort begun in the 1960s, the health transformation plan (HTP) devised comprehensive strategies to improve the key performances of the health system, such as governance, financing and service provision ${ }^{12,35,39}$. The HTP in Turkey had three main initiatives including introduction of the public health insurance scheme, improving public health care and introducing the family physician program, and empowering hospitals to achieve financial and administrative independence ${ }^{36,62}$. The experience of Turkey, Thailand and South Korea show that if merging as a health financing reform is going to be effective it should be accompanied by other cost-limiting reforms like moving towards close-ended payment methods including capitation, and DRG, emphasizing on PHC 
services to constrain health care expenditures in the long run. In Turkey, the alignment of demand side and the supply side, made it possible to reach and keep the UHC and translate it into expand the access to services, especially for the poor. Evidence shows that although a better insurance coverage improves accessibility, the service package is realized in the presence of the interventions form the supply side ${ }^{12}$. In South Korea as the main payment method is fee-for-service, it is expected that by implementing "Moon Jae-in Care" the total health care expenditures will go up. So it has been advised that Moon Jae-in Care should emphasize more on primary health care and reorganize the health system by moving towards regionalization and reducing the pressure on tertiary health level ${ }^{26}$. Without clinging on restraining health care expenditures reforms it is difficult to keep the advantages we expect to get from merging.

\section{Feasibility of merging:}

The experience of countries showed that long-lasting financial sustainability especially by the government is a key prerequisite at least to continue and maintain (if not to start) creation of single national scheme for all. The Universal Health Coverage Scheme of Thailand is still facing multiple challenges. The National Health Security Office which manages the universal coverage scheme is currently financed through general taxation, which requires annual negotiations over the per capita budget with the Ministry of Finance. With changes in healthcare technologies and the aging of the population, it is expected that the costs of the program will increase, and the financial stability will be endangered. Therefore, alternative long-term financial mechanisms are necessary ${ }^{30}$. In Indonesia, the International Business Chamber of Commerce, which has representatives from different investor countries, demonstrated its opposition to the National Health Insurance Bill, in several occasions. In their analysis, the USAID consultant stated their concern over the effects of the Bill on the economy of Indonesia and mentioned that if the Bill were to be implemented, GDP would decrease by $1 \%{ }^{56}$. The findings showed that the financial stability, economic growth and also financial support of government is necessary to implement merging and create a single insurance as more financial support needs to cover population without coverage, increase the share of government from contribution rates on behalf of the poor and underprivileged groups, to enhance the benefit package for all, to support the national insurance scheme in the case of facing budget deficiency, to mandate employers and employees in the private sector to participate in the single national insurance and pay their own share of contribution rate and also to invest in health infrastructures in deprived and remote areas.

\section{Stakeholder analysis:}

Like other health reforms, the findings showed that merging health insurance together is a tough political decision. Many actors may oppose merging based on the interests and advantages they may lose or disadvantages they my face as a result of merging. Those with more generous benefit package may oppose sharing it with other underprivileged groups. Employers and employees enjoying low premium rates may concern about paying more contribution rates and those who work in health insurance organizations or even work agencies may oppose merger as it may jeopardize their job stability. Experience from Iran shows that apart from technical issues, the interests that actors may lose or gain 
due to merging matters a lot too which should be noticed carefully if policy makers are going to merge health insurance together ${ }^{20}$. These concerns can be more challenging where the health insurance scheme which is going to be center of merger is weaker than others in terms of benefit package, contribution rates, or even the amount of salary it pays to its employees.

\section{Problems ahead of merger resulting from the depth of differences among health insurance funds}

Most countries have gradually extended the universal health coverage. Due to the complex process, the required effort to achieve the support and agreement of the interest groups and the time-span needed for developing the organizational and technical capacities, countries choose a gradual approach toward providing insurance cover for different groups. The experience of countries show that the gradual health coverage development approach leads to the creation of multiple risk pools for different population groups with different levels of coverage. This creates new challenges for the assurance of equal coverage and redistribution of resources across risk pools, and once they are established, it will be politically difficult to merge or integrate them since this means that the privileged organized groups must lose some of their benefits in favor of other population groups ${ }^{15}$. Therefore, moving toward a single insurance and consolidation of insurance funds, like any other large-scale reform in the health system, have always faced resistance from interest groups.

As it was mentioned in the introduction, bigger differences among risk pools in terms of benefit package, contribution rates, financial resources, high skew in distribution of population under coverage of each scheme, out-of-pocket payments and quality of care make moving towards merging more difficult. The experience of selected countries showed that one of the source of resistance against and operational challenges of merging health insurance funds is related to setting new contribution rates for different group of the insured and modifying the benefit package in a way to satisfy all groups. According to Turkey, to make merging possible, to reduce the resistance of privileged groups, and to increase equity in access to health care services, government should support merging financially and extend the benefit package for underprivileged groups in terms of scope and depth of health services and even the range of health facilities in which beneficiaries are entitled to get health services they need. As in all countries the size and number of poor people who rely on the government to get health insurance coverage is considerable, this expansion in benefit package can put high financial pressure on the government. Merging should be considered as a policy window to formulate new contribution rates for different group of population bearing in mind the political resistance of privileged groups, improving the financial equity and ensuring financial sustainability of the national single health insurance after merging in the long term. The findings demonstrated that setting new contribution rates for the self-employed and those without coverage can be difficult, redistribution of governmental subsidies from privileged groups enjoying governmental budget in the favor of underprivileged groups and putting more financial obligation on the employees and employers can be challenging.

\section{Conclusion}


In many countries with health insurance system, there are different schemes for covering different parts of the population which are in part the result of the gradual development of insurance to cover different groups. This fragmentation in health insurance funds usually with different revenues and managerial structures will create differences in the operational procedures and different aspects of insurances. The more differences between health insurance funds, the more operational challenges and resistance should be addressed to create a single insurance scheme. This resistance prevented Thailand from achieving the single insurance system they wanted, and despite achieving universal coverage, the harmonization of the three government insurance schemes is still facing challenges and debates.

The merging of insurance funds and moving from multiple insurances to a single insurance system is difficult from both political and implementation viewpoints. As we mentioned, different groups are influenced by reducing the fragmentation, and their interests must be considered while merging the insurances. However, the experience of the selected countries showed that political commitment and determination of the government and administrators helped them pursue their goal despite facing oppositions and political challenges, and move toward establishment a single health insurance scheme.

It is important to remember that the merging of insurances is a complex, technical and political process which includes gradual process taking place in several years. Moreover, another lesson to be learned is that although the merger of insurance funds can bring about many benefits in the health insurance system and financial equity, it will not be the panacea to all problems of the health system. We need to carry out reforms in the supply side and the demand side simultaneously in order to bring about more positive outcomes for the health sector.

\section{Declarations}

Acknowledgments: We are thankful to all who participated in the study and enriched our findings with sharing their precious experience and information.

Authors' contributions: $A R$ and $M B$ have made substantial contributions to the conception of the work and have drafted the work. VYF and AB substantively revised, organized and enriched the manuscript. All authors read and approved the manuscript and agreed both to be personally accountable for the author's own contributions and to ensure that questions related to the accuracy or integrity of any part of the work.

Funding: We are grateful to the "Health Technology Assessment, Standardization and Tariff Department" of the Iranian Ministry of Health and Medical Education which provided the financial resources required for carrying out the study. The research team was obliged to address the requirements mentioned in the "Request for Proposal" provided by the funders. It's worth to mention that an observatory team on behalf of funders reviewed the study design proposed by the research team for several times but they did not participate in collection, analysis, and interpretation of data and in writing the manuscript. 
Availability of data and materials: The corresponding author will gladly provide any supporting materials upon request.

Ethics approval and consent to participate: Not applicable.

Consent for publication: Not applicable.

Competing interests: Authors declare that they have no competing interests. Vahid Yazdi-Feyzabadi is an Editorial Board Member.

\section{References}

1. Smith PC, Witter SN. Risk pooling in health care financing: the implications for health system performance. The International Bank for Reconstruction and Development / The World Bank: World Bank, Washington, DC; 2004.

2. Bazyar M, Rashidian A, Sakha MA, Mahdavi MRV, Doshmangir L. Combining health insurance funds in a fragmented context: what kind of challenges should be considered? BMC Health Services Research. 2020;20(1):1-14.

3. Pooling Health Funds and Risks. https://ieg.worldbankgroup.org/Data/reports/chapters/health_finance_chap3_update.pdf.

4. health systems financing, the path to universal coverage: World Health Organization, Technical Brief Series - Brief No 5; 2010.

5. Carrin G, James C. Reaching universal coverage via social health insurance: key design features in the transition period. 2004.

6. Pannarunothai $S$, Patmasiriwat $D$, Srithamrongsawat $S$. Universal health coverage in Thailand: ideas for reform and policy struggling. Health Policy. 2004;68(1):17-30. doi:http://dx.doi.org/10.1016/S0168-8510(03)00024-1

7. Organization WH. The world health report 2000: health systems: improving performance2000.

8. Organization WH. The World Health Report 2008: Primary health care (now more than ever)2008.

9. Organization WH. The World Health Report [2010]: Health Systems Financing; the Path to Universal Coverage2010.

10. Anderson GF, Hussey P. Special issues with single-payer health insurance systems. 2004.

11. Hussey P, Anderson GF. A comparison of single-and multi-payer health insurance systems and options for reform. Health Policy. 2003;66(3):215-228.

12. Atun R, Aydın S, Chakraborty $S$, et al. Universal health coverage in Turkey: enhancement of equity. The Lancet. 2013;382(9886):65-99.

13. Bärnighausen T, Sauerborn R. One hundred and eighteen years of the German health insurance system: are there any lessons for middle-and low-income countries? Social science \& medicine. 2002;54(10):1559-1587. 
14. Kwon S. Healthcare financing reform and the new single payer system in the Republic of Korea: Social solidarity or efficiency? International Social Security Review. 2003;56(1):75-94.

15. Maeda A, Araujo E, Cashin C, Harris J, Ikegami N, Reich MR. Universal health coverage for inclusive and sustainable development: a synthesis of 11 country case studies: World Bank Publications; 2014.

16. Thomson S, Foubister T, Mossialos E. Financing health care in the European Union Challenges and policy responses. World Health Organization: European Observatory on Health Systems and Policies; 2009.

17. Lagomarsino G, Garabrant A, Adyas A, Muga R, Otoo N. Moving towards universal health coverage: health insurance reforms in nine developing countries in Africa and Asia. The Lancet. 2012;380(9845):933-943.

18. Somanathan A, Tandon A, Dao HL, Hurt KL, Fuenzalida-Puelma HL. Moving toward Universal Coverage of Social Health Insurance in Vietnam Assessment and Options. washington DC: THE WORLD BANK; 2014.

19. Paris V, Devaux M, Wei L. Health systems institutional characteristics. A Survey of 29 OECD Countries. 2010.

20. Bazyar M, Rashidian A, Sakha MA, et al. Stakeholders analysis of merging social health insurance funds in Iran: what kind of interests they may gain or lose? The International journal of health planning and management. 2019;34(1):157-176.

21. Bazyar M, Rashidian A, Kane S, et al. Policy Options to Reduce Fragmentation in the Pooling of Health Insurance Funds in Iran. Int J Health Policy Manag. 2016;5(4):253-258.

22. Kwon S. Thirty years of national health insurance in South Korea: lessons for achieving universal health care coverage. Health policy and planning. 2009;24(1):63-71.

23. Kwon S. Achieving health insurance for all: Lessons from the Republic of Korea. Social Security Policy and Development Branch, International Labour Office. 2002;Working Paper No.1.

24. Chun C, Kim S, J L, Lee S. Republic of Korea: health system review. 2009.

25. Kim S. Solidarity, labour, and institution: The politics of health insurance reform in Japan and South Korea, University of Sheffield; 2017.

26. Lee Y, Kim S, Kim SY, Kim G. Ethical Consideration of National Health Insurance Reform for Universal Health Coverage in the Republic of Korea. Asian Bioethics Review. 2019;11(1):41-56.

27. Kim S. Solidarity, Coalition and Strategy: Health Insurance Reform in the South Korea. Available at SSRN 2475999. 2014.

28. Thabrany $\mathrm{H}$. Social health insurance in Indonesia: current status and the proposed national health insurance. Paper presented at: Social Health Insurance Workshop by WHO SEARO; 13-15 March2003.

29. Kwon S. Health Care Financing in Asia Key Issues and Challenges. Asia-Pacific Journal of Public Health. 2011;23(5):651-661. 
30. Hsiao W, Shaw R, Fraker A, et al. Social health insurance for developing nations. WBI Development Studies, The World Bank, Washington DC. 2006.

31. !!! INVALID CITATION !!! 11,16,22.

32. Yardim MS, Uner S. Equity in access to care in the era of health system reforms in Turkey. Health Policy. 2018;122(6):645-651.

33. GÜRSOY K. An Overview of Turkish Healthcare System after Health Transformation Program: Main Successes, Performance Assessment, Further Challenges, and Policy Options: available at: https://dergipark.org.tr/en/download/article-file/152166.

34. Akbulut Y, Sarp N, Ugurluoglu E. Reform of the health care system in Turkey: a review of universal health insurance. World Hospitals and Health Services. 2007;43(1):13.

35. ZAIM O, DiLER M. The Impacts of Health Sector Reform on the Efficiency and Productivity of Public and Private Hospitals in Turkey. Ankara Department of Economics, Bilkent University,Bilkent, Turkey.

36. Patient choice Nurse prescribing In: McDaid D, ed. Eurohealth. Vol 12. London: - London School of Economics Plolitical Science; 2006.

37. Yıldıım HH, Yıldııım T. Healthcare financing reform in Turkey: context and salient features. Journal of European Social Policy. 2011;21(2):178-193.

38. Tatar M, Mollahaliloğlu S, Şahin B, Aydın S, Maresso A, Hernández-Quevedo C. Turkey: Health system review. 2011.

39. YERELI AB. HEALTHCARE FINANCING REFORM: THE CASE in TURKEY.

40. Tirgil A, Dickens WT, Atun R. Effects of expanding a non-contributory health insurance scheme on out-of-pocket healthcare spending by the poor in Turkey. BMJ global health. 2019;4(4):e001540.

41. Tirgil A, Gurol-Urganci I, Atun R. Early experience of universal health coverage in Turkey on access to health services for the poor: regression kink design analysis. Journal of global health. 2018;8(2).

42. Towse A, Mills A, Tangcharoensathien V. Learning from Thailand's health reforms. Bmj. 2004;328(7431):103-105.

43. Tangcharoensathien V, Witthayapipopsakul W, Panichkriangkrai W, Patcharanarumol W, Mills A. Health systems development in Thailand: a solid platform for successful implementation of universal health coverage. The Lancet. 2018;391(10126):1205-1223.

44. Organization WH. The Kingdom of Thailand health system review: Manila: WHO Regional Office for the Western Pacific; 2015.

45. Mossialos E. Funding health care: options for Europe: Open University Press Maidenhead; 2002.

46. Tangcharoensathien V, Supachutikul A, Lertiendumrong J. The social security scheme in Thailand: what lessons can be drawn? Social science \& medicine. 1999;48(7):913-923.

47. Hanvoravongchai P. Health financing reform in Thailand: toward universal coverage under fiscal constraints. 2013.

48. Nonthaburi THISRO. Thailand's Universal Coverage Scheme: Achievements and Challenges, An independent assessment of the first 10 years (2001-2010): Nonthaburi, Thailand: Health Insurance 
System Research Office;2012.

49. Prakongsai P, Limwattananon S, Tangcharoensathien V. The equity impact of the universal coverage policy: lessons from Thailand. Innovations in health system finance in developing and transitional economies: Emerald Group Publishing Limited; 2009:57-81.

50. Pramualratana P, Wibulpolprasert S. Health insurance systems in Thailand: Health Systems Research Institute; 2002.

51. Thabrany H. Health Care Financing Arrangements: Experiences through Prepayment Mechanisms in Indonesia: Center for Health Economic Studies, University of Indonesia;2004.

52. Plummer V, Boyle M. Financing healthcare in Indonesia. Asia Pacific Journal of Health Management. 2016;11(2):33.

53. Mahendradhata Y, Trisnantoro L, Listyadewi S, et al. The Republic of Indonesia health system review. 2017.

54. Pisani E, Olivier Kok M, Nugroho K. Indonesia's road to universal health coverage: a political journey. Health policy and planning. 2017;32(2):267-276.

55. Agustina R, Dartanto T, Sitompul R, et al. Universal health coverage in Indonesia: concept, progress, and challenges. The Lancet. 2019;393(10166):75-102.

56. Thabrany H. Politics of National Health Insurance of Indonesia: A New Era of Universal Coverage. Presented at the 7th European Conference on Health Economics. 2008;Center for Health Economic and Policy Studies, University of Indonesia.

57. Simmonds A, Hort K. Institutional analysis of Indonesia's proposed road map to universal health coverage. Health Policy and Health Finance Knowledge Hub, The Nossal Institute for Global Health, The University of Melbourne. 2013.

58. Paris V, Devaux M, Wei L. Health systems institutional characteristics. 2010.

59. Daley C, Gubb J, Clarke E, Bidgood E. Healthcare Systems: The Netherlands. London: Civitas Health Unit. 2013.

60. Greß S, Groenewegen P, Kerssens J, Braun B, Wasem J. Free choice of sickness funds in regulated competition: evidence from Germany and the Netherlands. Health policy. 2002;60(3):235-254.

61. Kroneman M, Boerma W, Groenewegen P. Netherlands: health system review. Health systems in transition. 2016;18(2):1-240.

62. Menon R, Mollahaliloglu S, Postolovska I. Toward Universal Coverage: Turkey's Green Card Program for the Poor. 2013. 